\title{
Soil Fertility Status in Bukoba, Missenyi and Biharamulo Districts in Kagera Region, Tanzania
}

\author{
Mgeta Steven Merumba ${ }^{1,2, ~ *, ~ E r n e s t ~ S e m u ~}{ }^{1}$, Johnson Mashambo Semoka ${ }^{1}$, \\ Balthazar Michael Msanya ${ }^{1}$ \\ ${ }^{1}$ Department of Soil and Geological Sciences, Sokoine University of Agriculture, Morogoro, Tanzania \\ ${ }^{2}$ Maruku Research Centre, Tanzania Agricultural Research Institute (TARI), Bukoba, Tanzania \\ Email address: \\ smerumbason@gmail.com (M. S. Merumba),semu@suanet.ac.tz (E. Semu), semoka@yahoo.com (J. M. Semoka), \\ bmmsanya@gmail.com (B. M. Msanya) \\ ${ }^{*}$ Corresponding author
}

\section{To cite this article:}

Mgeta Steven Merumba, Ernest Semu, Johnson Mashambo Semoka, Balthazar Michael Msanya. Soil Fertility Status in Bukoba, Missenyi and Biharamulo Districts in Kagera Region, Tanzania. International Journal of Applied Agricultural Sciences. Vol. 6, No. 5, 2020 , pp. 96-117. doi: $10.11648 /$ j.ijaas.20200605.12

Received: September 5, 2020; Accepted: September 17, 2020; Published: September 23, 2020

\begin{abstract}
The study was conducted in three Districts of Kagera Region, Tanzania to assess the inherent soil fertility status of farmers' fields. Thirty-three fields, located three to five $\mathrm{km}$ apart, were selected and soil samples $(0-20 \mathrm{~cm}$ depth $)$ were taken, mixed thoroughly, air-dried, ground, sieved through $2 \mathrm{~mm}$ sieve, and analyzed in the soil laboratory based on standard laboratory analytical procedures. Correlation analyses among soil chemical properties were performed using IBM SPSS Statistic 20 and the mean values were calculated using Excel spreadsheet statistical package. Soil fertility index (SFI) and limiting nutrients were used to assess the fertility status of the fields. The results indicated that soil textures ranged from sandy clay loam to sandy clay, clay loam, clay to sandy. Soil pH ranged from strongly acid (5.1) to slightly acid (6.1) while EC levels were very low $\left(0.03-0.17 \mathrm{dS} \mathrm{m}^{-1}\right)$. Total $\mathrm{TN}$ ranged from very low to medium $(0.04-0.41 \%)$, extractable $\mathrm{P}$ ranged from low to high $\left(0.44-86.44 \mathrm{mg} \mathrm{kg}^{-1}\right)$ and Exchangeable $\mathrm{K}$ ranged from very low to medium $\left(0.08-0.98 \mathrm{cmol}^{(+)} \mathrm{kg}^{-1}\right)$. Exchangeable $\mathrm{S}$ ranged from low to medium $\left(2.27-12.14 \mathrm{mg} \mathrm{kg}^{-1}\right)$ while CEC ranged from very low to medium $\left(5.20-23.00 \mathrm{cmol}(+) \mathrm{kg}^{-1}\right)$, extractable $\mathrm{Zn}$ ranged from medium to high $\left(0.85-18.41 \mathrm{mg} \mathrm{kg}^{-1}\right), \mathrm{Cu}$ from medium to high $\left(0.47-2.81 \mathrm{mg} \mathrm{kg}{ }^{-1}\right)$, and Mn and Fe were medium $\left(2.24-70.34 \mathrm{mg} \mathrm{kg}^{-1}\right)$ and high $\left(37.50-473.21 \mathrm{mg} \mathrm{kg}^{-1}\right)$, respectively. The results also indicated both positive $(\mathrm{r}=+\mathrm{ve})$ and negative $(\mathrm{r}=-\mathrm{ve})$ and both significantly $(p \leq 0.05)$ and highly significantly $(p \leq 0.01)$ correlations among the soil chemical properties in each districts. Based on SFI, the soil fertility status of the studied fields ranged from poor fertility to good fertility. The results on the limiting nutrients across the studied fields indicated that $\mathrm{N}$ and $\mathrm{K}$ were the most limiting nutrients $(67 \%)$ followed by P (52\%), S (32\%), Mg and OC (18\%) and the least was Ca (15\%). The results also indicated that $\mathrm{N}$ and $\mathrm{P}$ were the most limiting nutrients in Bukoba District while $\mathrm{N}$ and $\mathrm{S}$ were the most limiting nutrients in Missenyi District and N, P and $\mathrm{K}$ were the most limiting nutrients in Biharamulo District. Therefore, specific soil fertility management practices are recommended based on limiting nutrients in those fields having inadequate levels of plant nutrients together with training of farmers on proper use of the appropriate soil fertility management practices.
\end{abstract}

Keywords: Soil Fertility Status, Soil Fertility Index, Physical and Chemical Properties, Soil Fertility Management, Limiting Nutrient (s), Kagera Region

\section{Introduction}

Agricultural production in the sub-Saharan Africa (SSA) has continued to decline due to increasing human population and land use intensification [1], due to decreased size of land available to farmers, reduced soil fertility and low crop productivity [2]. However, smallholder farmers are continuing to cultivate the available land to ensure household 
food security. Continued crop cultivation without replenishing the mined nutrients led to organic matter and soil nutrient depletion on smallholder farms [3-5], causing land degradation due to poor soil fertility $[6,7]$. Tanzania, being among the sub-Saharan Africa (SSA) countries, is also affected by declining crop productivity at farm level [8] due to continued crop cultivation without replenishing the nutrients by external inputs [9]. For example, in Kagera region, average root yield of cassava in farmers' fields is about $7 \mathrm{MT} \mathrm{ha}^{-1}[10,9]$ as compared to the national current average root yield of $10 \mathrm{MT} \mathrm{ha}^{-1}$ and potential yield of 25 to $60 \mathrm{MT} \mathrm{ha}^{-1}$ [8]. The average yield of maize in Kagera region is $1.6 \mathrm{MT} \mathrm{ha}^{-1}$ compared to the national current average yield of $4 \mathrm{MT} \mathrm{ha}^{-1}[10]$. The low yield is due among others, to the increased susceptibility of the crops to pests, and low soil fertility $[11,12]$. The low soil fertility has been attributed to the extensive loss of nutrients through leaching especially in high rainfall zone (above $1800 \mathrm{~mm}$ ), extensive weathering of the soils, low soil organic matter content and continuous crop removal of the nutrients from the soils without replenishment [13]. This suggests the need to use fertilizers in those soils to improve the soil fertility status for optimum and sustainable crop yields. However, before deciding on fertilizer use, farmers need to understand the inherent soil fertility status of their farms.

Soil is a dynamic natural medium from which plants get nutrients and mechanical support. It is a complex system comprised of minerals, soil organic matter (SOM), water, and air in different proportions [14]. Soil quality comprises interactive attributes of physical, chemical, and biological properties, which affect processes in the soil that make it suitable for agricultural uses [15]. Some of the chemical properties of the soil include soil reaction $(\mathrm{pH})$, organic matter, and macro- and micro-nutrients while physical properties include soil colour, soil texture, and structure. These properties vary spatially and temporally from a field to a larger region scale and are influenced by soil formation factors. These factors include soil parent materials, living organisms, time and relief (intrinsic factors), as well as soil management practices, fertilization and crop rotation (extrinsic factors) [16]. Physical and chemical soil properties play an important role for the soil fertility and are determined after soil testing [17].

Soil fertility assessment is the measurement of available plant nutrients and estimation of capacity of soil to maintain a continuous supply of plant nutrients for crops. It is the most basic decision making tool on a particular land use system [18] and it provides information regarding nutrient availability in soils, which forms the basis for fertilizer recommendations for economic and sustainable crops production [5]. It also helps to establish appropriate soil fertility management strategies for farmers, extension staff, and policy makers to improve soil fertility and crop productivity. Thus, understanding soil fertility status of the land at a particular location will help agricultural stakeholders including farmers to make decisions on how to use and manage the respective land for sustainable crop production. However, there is scanty information on the current fertility status of the soils in Kagera Region. It is for this reason that this study was conducted for the objective of assessing the fertility status of some selected fields as proxy to the soil fertility status of Bukoba, Missenyi and Biharamulo Districts. This will lead to formulation of recommendations on appropriate soil fertility management strategies to improve crop productivity at farm level and the region as whole, thereby improving household food security and income.

\section{Materials and Methods}

\subsection{Description of the Study Area}

\subsubsection{Location of the Study Area}

Kagera region is located on the north-western corner of Tanzania bordering the western shore of Lake Victoria (Figure 1). It lies between latitudes $1^{\circ} 00^{\prime}$ and $2^{\circ} 45^{\prime}$ south of the Equator and between longitudes $30^{\circ} 25^{\prime}$ and $32^{\circ} 40^{\prime}$ east of the Greenwich. It is the fifteenth largest region in Tanzania with an area of about 3,568,600 ha of land, which accounts for approximately 3.3\% Tanzania's total land area. However, out of region area, about 10,173 ha are enclosed by water of the Lake Victoria, Ikimba and Burigi, and the Ngono and Kagera rivers [19, 20]. Administratively, the region has seven districts, namely Bukoba, Biharamulo, Muleba, Karagwe, Ngara, Kyerwa, and Missenyi and borders three countries, namely Uganda, Rwanda and Burundi, (Figure 1). This study was conducted in three districts, namely Bukoba, Missenyi and Biharamulo. Bukoba District covers an area of 284,100 ha and is situated between latitudes $01^{\circ} 00^{\prime}$ and $03^{\circ} 00^{\prime} \mathrm{S}$ and between longitudes $030^{\circ} 45^{\prime}$ and $031^{\circ} 00^{\prime} \mathrm{E}$, with altitude ranging from 1200 - 1400 meters above sea level. Missenyi District covers an area of 270,875 ha and is situated between latitudes $01^{\circ} 00^{\prime}$ and $01^{\circ} 30^{\prime} \mathrm{S}$ and between longitudes $030^{\circ}$ $48^{\prime}$ and $031^{\circ} 49^{\prime} \mathrm{E}$, with altitude ranging from $1100-1400$ meters above sea level. Biharamulo District covers an area of 374,400 ha and is situated between latitudes $02^{\circ} 15^{\prime}$ and $03^{\circ}$ $15^{\prime} \mathrm{S}$ and between longitudes $031^{\circ} 00^{\prime}$ and $032^{\circ} 00^{\prime} \mathrm{E}$, with altitude ranging from 1100 - 1700 meters above sea level [21, 20].

\subsubsection{Climate and Soils of the Study Area}

The study area experiences bimodal rain seasons ranging from September to December (short rains) and from March to June (long rains). The average annual rainfall ranges from 900 - >2500 mm in Bukoba District, from $600-2000 \mathrm{~mm}$ in Missenyi District and from $700-1000 \mathrm{~mm}$ in Biharamulo District $[21,9,20]$. Based on rainfall intensity, three agroecological zones, namely high (Bukoba), medium (Missenyi), and low (Biharamulo) rainfall zones are found in Kagera Region [13]. Average annual temperature ranges from 16 $28^{\circ} \mathrm{C}$, with Missenyi District having higher annual temperature $\left(28^{\circ} \mathrm{C}\right)$ than Bukoba and Biharamulo Districts $\left(26^{\circ} \mathrm{C}\right)$. The soils range from sandy clay loam to sandy clay and clay [21]. 


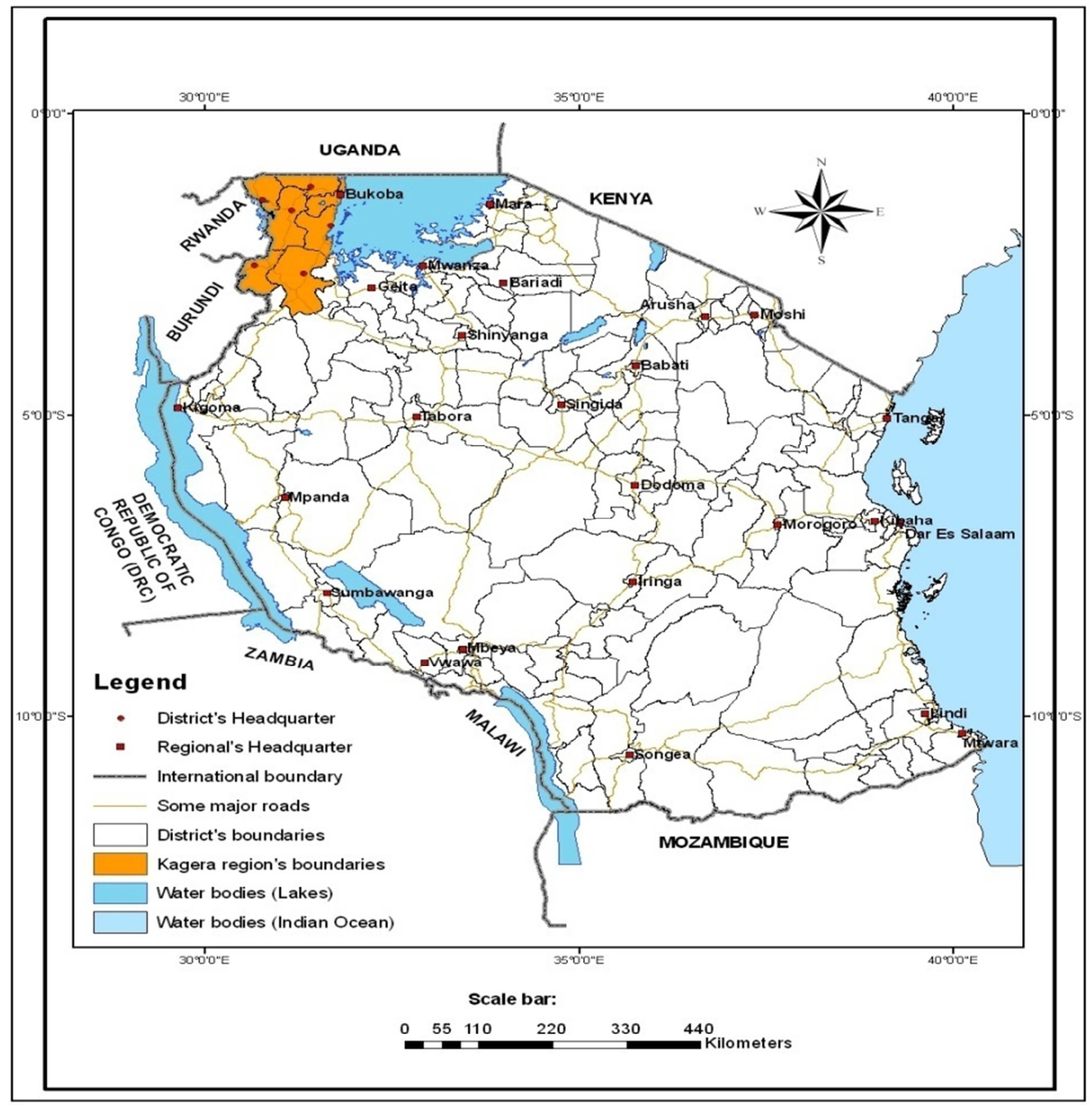

Source: [20]

Figure 1. Location of Kagera Region and its Districts, Tanzania.

\subsubsection{Farming Systems of the Study Area}

The farming systems of the study area are largely banana/coffee based [22], with three distinct land use types classified in local parlance "Haya" as Kibanja (Bibanja in plural). This is the most fertile land that usually surrounds the residential houses, and is permanently planted with the perennial crops, mainly banana (Mussa spp,), and coffee (Coffee canephora). The permanent crops are seasonally intercropped with annual crops, mainly beans (Phaseolus vulgaris), maize (maize (Zea mays), taro (Colocasia esculent), cassava (Mahihot esculenta) and various types of trees but the major crops being banana, coffee and beans. Another land use type is Kikamba, the area for annual crop cultivation found near Kibanja. Crops grown in Kikamba include cassava, maize, sweet potato (Ipomea potatos), yams (Dioscorea spp.) and occasionally taro, which are grown solely or mixed. The last land use type is Rweya, the grassland further away, serving as communal grazing land, source of mulch, thatch grass and area for shifting cultivation. Crops cultivated on Rweya under shifting cultivation include cassava, sweet potato and yams while tea (Cammelia sinensis) and trees like Eucalyptus spp. and Pinus spp. are permanently grown $[13,22,20]$. Soil sampling for this study therefore was done on Kikamba land use type, as it is the land where annual crops are grown. 


\subsection{Site Selection and Soil Sampling}

This study was conducted in Bukoba, Missenyi and Biharamulo Districts. In each District, two wards were selected. In each selected ward, one village was selected, thus giving two villages per each District. In each of the selected villages, five farmers' fields were selected to give 10 farmers' fields per District, which gave 30 farmers' fields in the three districts. In addition, one field in each district for the establishment of cassava experimental trial was selected to give 33 fields in the study area. The experimental trial sites were Tanzania Agricultural Research Institute (TARI), Maruku Centre in Bukoba District, Mabuye Primary school in Missenyi District and Rukaragata Farmers Extension Centre in Biharamulo District. The distance from one field to the other ranged from $3-5 \mathrm{~km}$ depending on the size of the villages. The size of the fields ranged from $0.4-1.2$ ha. In each of the selected fields, a soil sample $(0-20 \mathrm{~cm}$ depth $)$ was collected using a zig-zag pattern over the whole field area using soil auger from at least 20 spots within the field, which were then thoroughly mixed to get one composite soil sample. At least one $\mathrm{kg}$ of each composite soil sample, obtained through the quartering procedure, was air-dried, ground, sieved to pass through $2 \mathrm{~mm}$ sieve, packed, and labeled for laboratory analysis. A global positioning system (GPS) (model GARMIN etrex 20) was used to locate the geographical position of each selected field. A map showing the location of the evaluated fields was produced.

\subsection{Laboratory Soil Analysis}

Laboratory analysis was done at Sokoine University of Agriculture (SUA) Soil Science Laboratory. The parameters analyzed were particle size distribution, soil $\mathrm{pH}$, organic carbon (OC), total nitrogen (TN), available phosphorus (P), exchangeable bases $(\mathrm{Ca}, \mathrm{Mg}, \mathrm{K}$ and $\mathrm{Na})$, cation exchange capacity (CEC), extractable sulphur (S), iron (Fe), manganese $(\mathrm{Mn})$, zinc $(\mathrm{Zn})$ and copper $(\mathrm{Cu})$. Particle size distribution was determined by the Bouyoucos hydrometer method [23, 24] after dispersing the soils with sodium hexametaphosphate followed by determining textural classes using the USDA textural triangle [25].

Soil $\mathrm{pH}$ in water and electrical conductivity (EC) were measured potentiometrically $[24,26]$ in a soil: water ratio of 1:2.5 weight to volume basis using a soil $\mathrm{pH}$-meter for soil $\mathrm{pH}$ and an EC-meter for electrical conductivity. Organic carbon $(\mathrm{OC})$ was determined by the Walkey- Black wet oxidation method [27] and the OC values were converted to organic matter $(\mathrm{OM})$ by multiplying $\mathrm{OC}$ values by a factor of $1.724[28,17]$. Total nitrogen (TN) was determined by the micro-Kjeldahl digestion method [29]. Extractable phosphorus (P) was determined by the Bray and Kurtz-1 method [30] followed by colour development by the molybdenum blue method [31]. An ultraviolent visible (UV/VIS) spectrophotometer [32] was used to determine the quantity of available $\mathrm{P}$ in the soil.

The cation exchange capacity (CEC) of the soil and exchangeable bases $\left(\mathrm{Ca}^{+2}, \mathrm{Mg}^{+2}, \mathrm{~K}^{+}\right.$and $\left.\mathrm{Na}^{+}\right)$were extracted by the ammonium acetate $\left(\mathrm{NH}_{4} \mathrm{OAc}\right)-\mathrm{pH} 7$ saturation method [33] and determined using an atomic absorption spectrophotometer (AAS) [32] for $\mathrm{Ca}^{+2}$ and $\mathrm{Mg}^{+2}$ and flame photometer for $\mathrm{K}^{+}$and $\mathrm{Na}^{+}$[24]. The adsorbed $\mathrm{NH}_{4}^{+}$was displaced by $\mathrm{K}^{+}$using $1 \mathrm{M} \mathrm{KCl}$ followed by determination of CEC [34] by the micro-Kjeldahl distillation method [29, 24]. Extractable sulphur $\left(\mathrm{SO}_{4}^{2-}-\mathrm{S}\right)$ was extracted using calcium monophosphate $\left[\mathrm{Ca}\left(\mathrm{H}_{2} \mathrm{PO}_{4}\right)_{2} \cdot \mathrm{H}_{2} \mathrm{O}\right]$, following the development of particle suspensions (intensity of a beam of light) by the turbidimetric method (Moberg, 2001). An ultraviolent visible (UV/VIS) spectrophotometer [32] was used to determine the quantity of extractable $\mathrm{SO}_{4}{ }^{2-}-\mathrm{S}$ in the soil [24]. Micronutrients ( $\mathrm{Cu}, \mathrm{Fe}, \mathrm{Zn}$, and $\mathrm{Mn})$ extracted by the diethylene-triamine-penta-acetic acid (DTPA) method [35, $33,24]$ were determined using an atomic absorption spectrophotometer [32].

The total exchangeable base (TEB) was calculated as the sum of the four exchangeable bases $\left(\mathrm{Ca}^{2+}, \mathrm{Mg}^{2+}, \mathrm{K}^{+}\right.$and $\left.\mathrm{Na}^{+}\right)$ for a given soil sample. The $\mathrm{C}: \mathrm{N}$ ratio, silt: clay ratio, exchangeable sodium percentage (ESP) and percentage base saturation (BS \%) were calculated using formulars by [36].

\subsection{Statistical Analysis}

Correlation analysis of the soil parameters was performed using IBM SPSS Statistic 20 and the mean values of the soil parameters were calculated using the Excel spreadsheet statistical package.

\subsection{Soil Fertility Status Determination Using the Soil Fertility Index}

There are direct and indirect ways of evaluating soil fertility status. Direct evaluation is carried out in the field, greenhouses or laboratory by means of experiments carried out under given climatic and management conditions [37]. Indirect evaluation consists of developing and applying models of varying complexity. One of the most suitable models is the soil fertility index (SFI) model [37-39], which uses the parametric approach for each soil to identify its fertility status using SFI classes. Each soil is evaluated based on factor ratings ranging between 10 and 100 using a rating value of each soil parameter [37] (Table 1). The least favourable value of factor rating is 10 and the most beneficial value of factor rating is 100 . Therefore, soil fertility index in this study was calculated using the values of factor rating for each soil parameter using the SFI model (Formula 1).

$$
\mathrm{SFI}=\operatorname{Rmax} \times \sqrt{\sum_{\mathrm{n}=1}^{\mathrm{n}=13} \frac{\mathrm{F}}{100}}
$$

Where:

$\mathrm{F}=$ Factor rating of each soil parameter

$$
\mathrm{R} \max \left(\text { maximum ratio) }=\frac{\mathrm{V} 1+\mathrm{V} 2+\mathrm{V} 3+\mathrm{V} 4+\mathrm{V} 5 \ldots \ldots \ldots \ldots \ldots \ldots \ldots . . . \mathrm{V} 13}{13}\right.
$$

$\mathrm{V}=$ Rating value for each soil parameter

Thereafter, the soil fertility status of the studied fields was 
identified based on classes and values of the soil fertility index (Table 2).

Table 1. Factor ratings and rating values of soil parameters.

\begin{tabular}{|c|c|c|c|c|c|}
\hline \multirow{2}{*}{ Soil parameter } & \multicolumn{5}{|l|}{ Factor rating } \\
\hline & 100 & 80 & 50 & 20 & 10 \\
\hline $\mathrm{pH}(1: 2.5$; soil: water $)$ & $65-7.5$ & $7.4-8.5$ & $5.5-6.4$ & $4.5-5.4$ & $<4.5->8.5$ \\
\hline $\mathrm{EC}\left(\mathrm{dS} \mathrm{m}^{-1}\right)$ & $0-2$ & $2.1-4$ & $4.1-6$ & $6.1-8$ & $>8$ \\
\hline $\operatorname{SOM}\left(\mathrm{g} \mathrm{kg}^{-1}\right)$ & $>30$ & $20.1-30$ & $10.1-20$ & $5.1-10$ & $0-5$ \\
\hline $\mathrm{TN}\left(\mathrm{g} \mathrm{kg}^{-1}\right)$ & $>3.20$ & $1.71-3.20$ & $0.91-1.70$ & $0.45-0.90$ & $<0.45$ \\
\hline $\mathrm{P}\left(\mathrm{mg} \mathrm{kg}^{-1}\right)$ & $>80$ & $25.1-80$ & $8.1-25$ & $2.5-8.0$ & $<2.5$ \\
\hline $\mathrm{Ca}\left(\mathrm{cmol}(+) \mathrm{kg}^{-1}\right)$ & $17.6-50$ & $5.76-17.5$ & $1.19-5.75$ & $>50$ & $<1.19$ \\
\hline $\mathrm{Mg}\left(\mathrm{cmol}(+) \mathrm{kg}^{-1}\right)$ & $>12.5$ & $4.1-12.5$ & $1.34-4.0$ & $0.42-1.33$ & $<0.42$ \\
\hline $\mathrm{K}\left(\mathrm{cmol}(+) \mathrm{kg}^{-1}\right)$ & $0.29-0.74$ & $0.75-2.56$ & $0.13-0.28$ & $>2.56$ & $<0.13$ \\
\hline $\mathrm{Na}\left(\mathrm{cmol}(+) \mathrm{kg}^{-1}\right)$ & $0-0.20$ & $0.21-0.30$ & $0.31-0.70$ & $0.71-2.0$ & $>2.0$ \\
\hline $\mathrm{Zn}\left(\mathrm{mg} \mathrm{kg}^{-1}\right)$ & $0.71-2.41$ & $2.4-8.0$ & $0.2-0.7$ & $>8$ & $<0.2$ \\
\hline $\mathrm{Fe}\left(\mathrm{mg} \mathrm{kg}^{-1}\right)$ & $2.1-4.5$ & $1,1-2.0$ & $0.2-1.0$ & $>4.5$ & $<0.2$ \\
\hline $\operatorname{Mn}\left(\mathrm{mg} \mathrm{kg}^{-1}\right)$ & $15-50$ & $4-14$ & $50-170$ & $>170$ & $<4$ \\
\hline $\mathrm{Cu}\left(\mathrm{mg} \mathrm{kg}^{-1}\right)$ & $>0.2$ & & & & $<0.2$ \\
\hline Soil Textural class & CL, SCL, SiCL & vfSL, L, SiL, Si & C, SC, SiC & SL, fSL & S, LS \\
\hline
\end{tabular}

Source: [37].

Chemical property: $\mathrm{EC}=$ electric conductivity, $\mathrm{SOM}=$ soil organic matter, $\mathrm{TN}=$ total nitrogen, $\mathrm{C}: \mathrm{N}=$ carbon: nitrogen ratio, $\mathrm{P}=$ phosphorus, $\mathrm{SO}_{4}$ - $\mathrm{S}=$ sulphate sulphur, $\mathrm{Ca}=$ calcium, $\mathrm{Mg}=$ magnessium, $\mathrm{K}=$ potassium, $\mathrm{Na}=$ sodium, $\mathrm{CEC}=$ cation exchange capacity, $\mathrm{ESP}=$ exchangeable sodium percentage, $\mathrm{BS}=$ base saturation, $\mathrm{Zn}=\mathrm{zinc}, \mathrm{Fe}=$ iron, $\mathrm{Mn}=$ manganese, $\mathrm{Cu}=$ copper,

Textural class: $\mathrm{CL}=$ clay loam, $\mathrm{SCL}=$ sandy clay loam, $\mathrm{SiCL}=$ silty clay loam, $\mathrm{vfSL}=$ very fine sandy loam, $\mathrm{L}$ - loam, $\mathrm{SiL}=$ silty loam, $\mathrm{Si}=$ silt, $\mathrm{C}=$ clay, $\mathrm{SC}=$ sandy clay, $\mathrm{SiC}=$ silty clay, $\mathrm{SL}=$ sandy loam, $\mathrm{fSL}=$ fine sandy loam, $\mathrm{S}=$ sand, $\mathrm{LS}=$ loamy sand.

\section{Results and Discussion}

\subsection{Locations of the Studied Fields in the Study Area}

Locations of the studied fields (Figure 2) were between latitudes $01^{\circ} 12^{\prime}$ and $02^{\circ} 24^{\prime} \mathrm{S}$, and between longitudes $031^{\circ}$ $46^{\prime}$ and $031^{\circ} 50^{\prime} \mathrm{E}$, with altitude ranging from $1226-1345$ meters above sea level (masl) in Bukoba District. In Missenyi District, the studied fields were between latitudes $01^{\circ} 06^{\prime}$ and $01^{\circ} 11^{\prime} \mathrm{S}$ and between longitudes $031^{\circ} 23^{\prime}$ and $031^{\circ} 27^{\prime} \mathrm{E}$, with altitude ranging from 1140 - 1240 masl. In Biharamulo
District, the studied fields were between latitudes $02^{\circ} 38^{\prime}$ and $02^{\circ} 40^{\prime} \mathrm{S}$ and between longitudes $031^{\circ} 18^{\prime}$ and $031^{\circ} 23^{\prime} \mathrm{E}$, with altitude ranging from $1251-1480$ masl (Table 3 ).

Table 2. Classes and values of soil fertility index.

\begin{tabular}{lll}
\hline Class & Soil fertility index & Description \\
\hline S1 & $>80$ & Good fertility \\
S2 & $80-51$ & Moderate fertility \\
S3 & $50-20$ & Marginal fertility \\
N & $<20$ & Poor fertility \\
\hline
\end{tabular}

Source: $[38,39,37]$.

Table 3. Geographical locations of the studied fields in Bukoba, Missenyi and Biharamulo Districts, Tanzania.

\begin{tabular}{|c|c|c|c|c|c|}
\hline \multirow{2}{*}{ District } & \multirow{2}{*}{ Village } & \multirow{2}{*}{ Silo sampling site } & \multicolumn{3}{|c|}{ Geographical location } \\
\hline & & & Latitude (S) & Longitude (E) & Altitude (masl) \\
\hline \multirow[t]{11}{*}{ Bukoba } & Butairuka & Rushabirwa farm & $01^{\circ} 24^{\prime} 20.4^{\prime \prime}$ & $031^{\circ} 46^{\prime} 43.9^{\prime \prime}$ & 1345 \\
\hline & & Mpanju farm & $01^{\circ} 2421.1^{\prime \prime}$ & $031^{\circ} 47^{\prime} 18.8^{\prime \prime}$ & 1330 \\
\hline & & Kahigi farm & $01^{\circ} 24^{\prime} 31.1^{\prime \prime}$ & $031^{\circ} 47^{\prime} 36.7^{\prime \prime}$ & 1305 \\
\hline & & Bana farm & $01^{\circ} 24^{\prime} 53.8^{\prime \prime}$ & $031^{\circ} 49^{\prime} 53.9^{\prime \prime}$ & 1331 \\
\hline & & Kyabitara farm & $01^{\circ} 15^{\prime} 17.5^{\prime \prime}$ & $031^{\circ} 47^{\prime} 20.1^{\prime \prime}$ & 1360 \\
\hline & Kiilima & Degratias farm & $01^{\circ} 12^{\prime} 57.4^{\prime \prime}$ & $031^{\circ} 50^{\prime} 56.8^{\prime \prime}$ & 1226 \\
\hline & & Ifunya farm & $01^{\circ} 13^{\prime} 40.0^{\prime \prime}$ & $031^{\circ} 50^{\prime} 19.4^{\prime \prime}$ & 1229 \\
\hline & & Baguma farm & $01^{\circ} 12^{\prime} 50.7^{\prime \prime}$ & $031^{\circ} 49^{\prime} 27.1^{\prime \prime}$ & 1250 \\
\hline & & Respicius farm & $01^{\circ} 14^{\prime} 30.5^{\prime \prime}$ & $031^{\circ} 49^{\prime} 53.9^{\prime \prime}$ & 1258 \\
\hline & & Godwin farm & $01^{\circ} 15^{\prime} 17.5^{\prime \prime}$ & $031^{\circ} 50^{\prime} 05.1^{\prime \prime}$ & 1263 \\
\hline & & TARI- Maruku Centre & $01^{\circ} 25^{\prime} 01.7^{\prime \prime}$ & $031^{\circ} 46^{\prime} 39.4^{\prime \prime}$ & 1350 \\
\hline \multirow[t]{10}{*}{ Missenyi } & Igayaza & Farmers Extension Centre & $01^{\circ} 07^{\prime} 29.2^{\prime \prime}$ & $031^{\circ} 23^{\prime} 35.0^{\prime \prime}$ & 1240 \\
\hline & & Masood farm & $01^{\circ} 08^{\prime} 48.8^{\prime \prime}$ & $031^{\circ} 24^{\prime} 52.0^{\prime \prime}$ & 1159 \\
\hline & & Kaloli farm & $01^{\circ} 09^{\prime} 09.4^{\prime \prime}$ & $031^{\circ} 23^{\prime} 17.9^{\prime \prime}$ & 1193 \\
\hline & & Rubega farm & $01^{\circ} 08^{\prime} 13.2^{\prime \prime}$ & $031^{\circ} 23^{\prime} 33.3^{\prime \prime}$ & 1217 \\
\hline & & Tautus farm & $01^{\circ} 06^{\prime} 48.8^{\prime \prime}$ & $031^{\circ} 23^{\prime} 59.3^{\prime \prime}$ & 1208 \\
\hline & Mabuye & Mhonge farm & $01^{\circ} 09^{\prime} 30.1^{\prime \prime}$ & $031^{\circ} 27^{\prime} 17.9^{\prime \prime}$ & 1140 \\
\hline & & Maida farm & $01^{\circ} 10^{\prime} 28.2^{\prime \prime}$ & $031^{\circ} 26^{\prime} 42.1^{\prime \prime}$ & 1142 \\
\hline & & Mabuye society & $01^{\circ} 11^{\prime} 00.2^{\prime \prime}$ & $031^{\circ} 27^{\prime} 17.1^{\prime \prime}$ & 1153 \\
\hline & & Pascal farm & $01^{\circ} 10^{\prime} 40.3^{\prime \prime}$ & $031^{\circ} 25^{\prime} 24.9^{\prime \prime}$ & 1153 \\
\hline & & Gervas farm & $01^{\circ} 11^{\prime} 46.8^{\prime \prime}$ & $031^{\circ} 25^{\prime} 48.6^{\prime \prime}$ & 1149 \\
\hline
\end{tabular}




\begin{tabular}{|c|c|c|c|c|c|}
\hline \multirow{2}{*}{ District } & \multirow{2}{*}{ Village } & \multirow{2}{*}{ Silo sampling site } & \multicolumn{3}{|c|}{ Geographical location } \\
\hline & & & Latitude (S) & Longitude (E) & Altitude (masl) \\
\hline \multirow{12}{*}{ Biharamulo } & \multirow{4}{*}{ Rukirwengama } & Mabuye Primary School & $01^{\circ} 11^{\prime} 38.1^{\prime \prime}$ & $031^{\circ} 26^{\prime} 00.8^{\prime \prime}$ & 1159 \\
\hline & & Edmund farm & $02^{\circ} 39^{\prime} 51.1 "$ & $031^{\circ} 21^{\prime} 06.0^{\prime \prime}$ & 1424 \\
\hline & & Benjamin farm & $02^{\circ} 39^{\prime} 06.5^{\prime \prime}$ & $031^{\circ} 23^{\prime} 15.5^{\prime \prime}$ & 1460 \\
\hline & & Chubwa farm & $02^{\circ} 38^{\prime} 47.1^{\prime \prime}$ & $031^{\circ} 23^{\prime} 51.8^{\prime \prime}$ & 1449 \\
\hline & \multirow{8}{*}{ Rukaragata } & Wilson farm & $02^{\circ} 38^{\prime} 01.5^{\prime \prime}$ & $031^{\circ} 22^{\prime} 43.9^{\prime \prime}$ & 1445 \\
\hline & & Mtanzania farm & $02^{\circ} 38^{\prime} 58.6^{\prime \prime}$ & $031^{\circ} 22^{\prime} 10.9^{\prime \prime}$ & 1251 \\
\hline & & Yustina farm & $02^{\circ} 39^{\prime} 17.2^{\prime \prime}$ & $031^{\circ} 18^{\prime} 17.3^{\prime \prime}$ & 1434 \\
\hline & & Chinga farm & $02^{\circ} 40^{\prime} 19.1 "$ & $031^{\circ} 18^{\prime} 07.8^{\prime \prime}$ & 1480 \\
\hline & & Mkanirwa farm & $02^{\circ} 39^{\prime} 51.5^{\prime \prime}$ & $031^{\circ} 18^{\prime} 33.8^{\prime \prime}$ & 1444 \\
\hline & & Village office & $02^{\circ} 40^{\prime} 03.6^{\prime \prime}$ & $031^{\circ} 18^{\prime} 52.7^{\prime \prime}$ & 1443 \\
\hline & & Mutalemwa farm & $02^{\circ} 39^{\prime} 19.3^{\prime \prime}$ & $031^{\circ} 19^{\prime} 03.0^{\prime \prime}$ & 1427 \\
\hline & & Farmers Extension Centre & $02^{\circ} 38^{\prime} 52.1^{\prime \prime}$ & $031^{\circ} 18^{\prime} 49.3^{\prime \prime}$ & 1427 \\
\hline
\end{tabular}

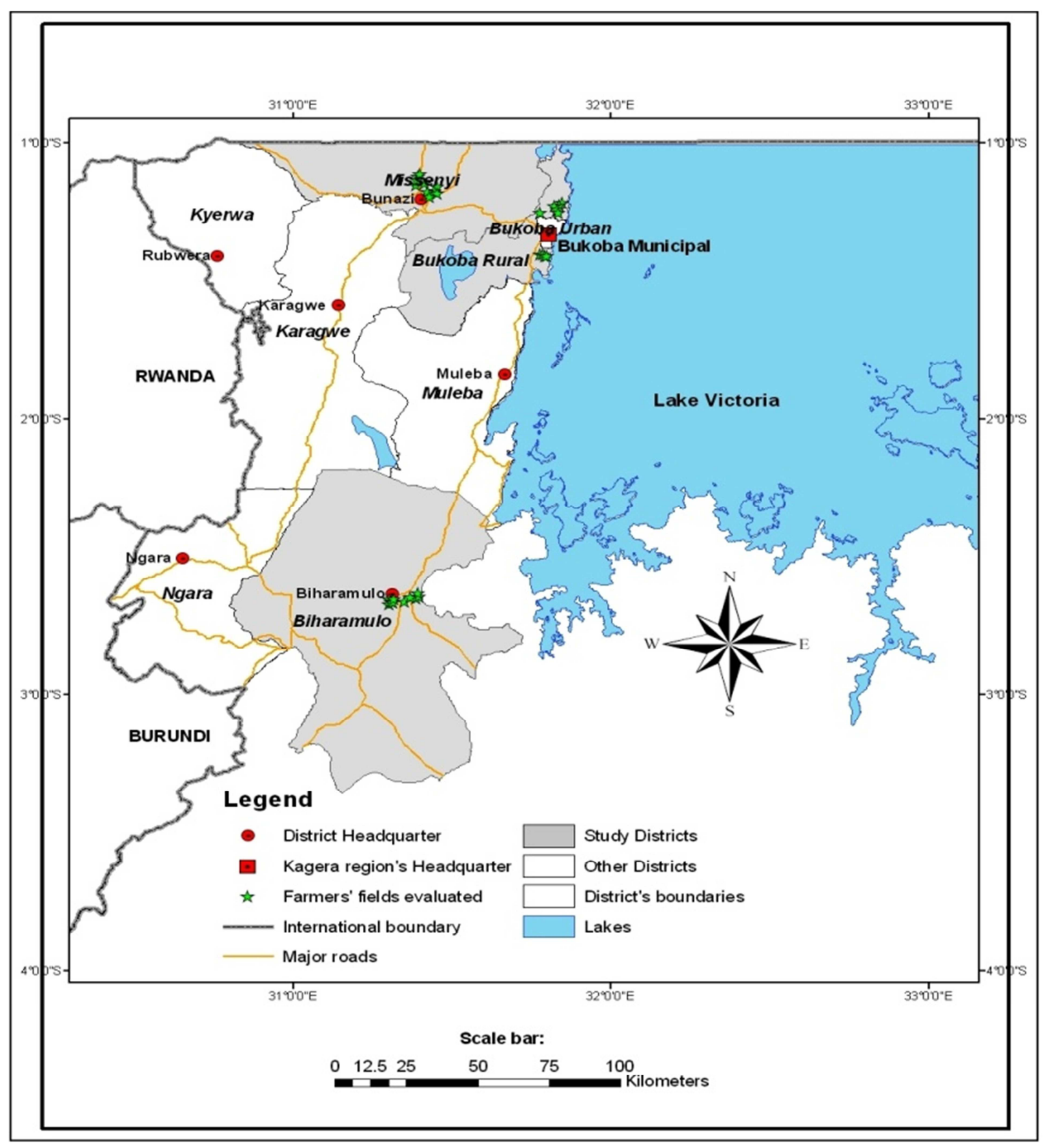

Figure 2. The map of Kagera Region, Tanzania showing fields evaluated in the study area. 


\subsection{Some Physical Properties of the Soils of the Studied Fields}

Soil textural classes of the studied fields ranged from sandy clay to sandy clay loam in Bukoba District, from sandy to clay and sandy clay loam in Missenyi District and from sandy loam to sandy clay loam in Biharamulo District (Table 4). In Bukoba District about, $64 \%$ and $36 \%$ of the studied fields had sandy clay loam and sandy clay soil texture, respectively. In Missenyi and Biharamulo Districts, the studied fields had diverse soil texture. In Missenyi District, about $37 \%, 18 \%, 18 \%, 18 \%$ and $9 \%$ of the studied fields had sandy clay loam, sandy clay, clay loam, clay, and sandy soil texture, respectively. In Biharamulo District, about $46 \%$, $36 \%, 9 \%$ and $9 \%$ of the studied fields had sandy clay loam, sandy clay, sandy loam and clay soil texture, respectively.

Nevertheless, the soil textures of many $(86.7 \%)$ fields are favourable for crop production since they allow root proliferation, aeration, water infiltration and holding capacity, soil nutrients retention and drainage $[17,37]$ as compared to few
(13.3\%) fields, which had clay and sandy soil texture. Clay texture has poor water infiltration, poor aeration, poor drainage and to some extent low root proliferation which can affect the performance of some crops like root crops. Sandy soil texture has poor water holding capacity, poor nutrient holding capacity and high water infiltration [17]. Therefore, incorporation of organic matter such as manure, compost, cover crops and crop residues in those soils is of great importance to improve soil particle aggregation, tilth, OM content, drainage, water holding capacity and soil nutrients retention capacity.

The silt: clay ratio is one of the soil parameters that signify the age of the soils as the lower the ratio the more weathered the soils are [40]. The silt: clay ratio of the soils of studied fields ranged from 0.13 - 0.49 in Bukoba District, from 0.12 0.76 in Missenyi District and from 0.07 - 0.59 in Biharamulo District. Therefore, based on the values of silty: clay ratio of the studied fields, the soils of many farms in Bukoba District were comparatively more weathered than those in Biharamulo District and the least weathered were those in Missenyi District.

Table 4. Particle size distribution of the studied soils in Bukoba, Missenyi, and Biharamulo Districts, Tanzania.

\begin{tabular}{|c|c|c|c|c|c|c|c|}
\hline \multirow{2}{*}{ District } & \multirow{2}{*}{ Village } & \multirow{2}{*}{ Soil sampling site } & \multicolumn{3}{|c|}{ Particle size (\%) } & \multirow{2}{*}{ Textural class } & \multirow{2}{*}{ Silt: Clay ratio } \\
\hline & & & Sand & Silt & Clay & & \\
\hline \multirow[t]{10}{*}{ Bukoba } & \multirow[t]{6}{*}{ Butairuka } & Rushabirwa farm & 51.80 & 9.92 & 38.38 & $\mathrm{SC}$ & 0.26 \\
\hline & & Mpanju farm & 48.80 & 8.92 & 44.28 & $\mathrm{SC}$ & 0.20 \\
\hline & & Kahigi farm & 57.80 & 6.92 & 35.28 & $\mathrm{SC}$ & 0.20 \\
\hline & & Bana farm & 51.80 & 7.02 & 41.18 & $\mathrm{SC}$ & 0.17 \\
\hline & & Kyabitara farm & 52.80 & 11.92 & 35.28 & $\mathrm{SC}$ & 0.34 \\
\hline & & TARI Maruku Centre & 54.80 & 14.30 & 30.80 & SCL & 0.46 \\
\hline & \multirow{4}{*}{ Kiilima } & Ifunya farm & 62.80 & 5.92 & 31.28 & SCL & 0.19 \\
\hline & & Baguma farm & 51.80 & 15.92 & 32.28 & SCL & 0.49 \\
\hline & & Respicius farm & 62.80 & 7.92 & 29.28 & SCL & 0.27 \\
\hline & & Godwin farm & 56.80 & 4.92 & 38.28 & $\mathrm{SC}$ & 0.13 \\
\hline \multirow[t]{10}{*}{ Missenyi } & \multirow[t]{4}{*}{ Igayaza } & Farmers Extension Centre & 44.80 & 20.02 & 34.28 & $\mathrm{CL}$ & 0.58 \\
\hline & & Masood farm & 33.80 & 34.92 & 31.28 & CL & 1.12 \\
\hline & & Kaloli farm & 53.80 & 19.92 & 26.28 & SCL & 0.76 \\
\hline & & Rubega farm & 48.80 & 14.92 & 36.28 & $\mathrm{SC}$ & 0.41 \\
\hline & \multirow[t]{6}{*}{ Mabuye } & Mhonge farm & 28.80 & 24.92 & 46.28 & $\mathrm{C}$ & 0.54 \\
\hline & & Maida farm & 52.80 & 15.92 & 21.28 & SCL & 0.75 \\
\hline & & Mabuye society & 72.80 & 5.92 & 21.28 & SCL & 0.28 \\
\hline & & Pascal farm & 58.80 & 7.92 & 33.28 & SCL & 0.24 \\
\hline & & Gervas farm & 90.80 & 1.92 & 7.28 & S & 0.26 \\
\hline & & Mabuye Primary School & 74.80 & 7.28 & 17.92 & SL & 0.41 \\
\hline \multirow[t]{9}{*}{ Biharamulo } & \multirow[t]{5}{*}{ Rukirwengama } & Edmund farm & 61.80 & 8.92 & 29.28 & SCL & 0.30 \\
\hline & & Benjamin farm & 71.80 & 1.92 & 26.28 & SCL & 0.07 \\
\hline & & Chubwa farm & 77.80 & 2.92 & 19.28 & SL & 0.15 \\
\hline & & Wilson farm & 73.80 & 1.92 & 24.28 & SCL & 0.08 \\
\hline & & Mtanzania farm & 67.80 & 8.92 & 28.28 & SCL & 0.32 \\
\hline & \multirow[t]{4}{*}{ Rukaragata } & Yustina farm & 54.80 & 9.92 & 35.28 & $\mathrm{SC}$ & 0.28 \\
\hline & & Chinga farm & 35.80 & 8.92 & 55.28 & $\mathrm{C}$ & 0.16 \\
\hline & & Mkanirwa farm & 51.80 & 17.92 & 30.28 & SCL & 0.59 \\
\hline & & Village Office & 51.80 & 12.92 & 35.28 & $\mathrm{SC}$ & 0.37 \\
\hline
\end{tabular}

Soil textural class: $\mathrm{SC}=$ Sandy clay; $\mathrm{SCL}=$ Sandy clay loam; $\mathrm{CL}=$ Clay loam; $\mathrm{C}=\mathrm{Clay} ; \mathrm{S}=\mathrm{Sand}$; $\mathrm{SL}=\mathrm{Sandy}$ loam.

\subsection{Soil Chemical Properties}

\subsubsection{Soil pH and Electrical Conductivity}

The $\mathrm{pH}$ in water of the studied fields ranged from strongly acid (5.1) to medium acid (5.7) in Bukoba District, from strongly acid (5.2) to slightly acid (6.1) in Missenyi District and from strongly acid (5.1) to slightly acid (6.5) in 
Biharamulo District [36, 41-44] (Table 5). In Bukoba District, about $91 \%$ and $9 \%$ of the fields had strongly acid and moderately acid soil $\mathrm{pH}$, respectively. In Missenyi District, about $36 \%$ of the fields had strongly acid soil $\mathrm{pH}, 55 \%$ had moderately acid soil $\mathrm{pH}$ and $9 \%$ had slightly acid soil $\mathrm{pH}$. In Biharamulo District, about $55 \%$ of the studied fields had strongly acid soil $\mathrm{pH}, 27 \%$ had moderately acid soil $\mathrm{pH}$ and $18 \%$ had slightly acid soil $\mathrm{pH}$.

The low soil $\mathrm{pH}$ observed in many studied fields in Bukoba District as compared to Missenyi and Biharamulo Districts was due to the high rainfall $(>2500 \mathrm{~mm}$ ) experienced in Bukoba District [22, 9, 20]. Bukoba District is characterized as a high rainfall area $[13,22]$. High rainfall lead to leaching which removes the basic cations from the surface soil to the subsurface, leaving more $\mathrm{H}^{+}$in topsoil, hence low soil pH (more acidic condition) in topsoil [17]. Acid soils with low $\mathrm{pH}(<5.5)$ have a great potential for $\mathrm{Mn}$, $\mathrm{Al}$ and Fe toxicity, deficiencies of some essential nutrients and retardation of microbial activity. Poor microbial activity affects the decomposition of soil organic matter [36, 17]. The soils with $\mathrm{pH}<5.5$ can also cause the dissolution of $\mathrm{Al}$ and $\mathrm{Fe}$ minerals, which precipitates with $\mathrm{P}$, leading to $\mathrm{P}$ fixation $[36,17,45]$. Therefore, for optimum and sustainable crop production, application of liming materials such as calcium carbonate $\left(\mathrm{CaCO}_{3}\right)$ calcium hydroxide $\left(\mathrm{Ca}(\mathrm{OH})_{2}\right)$ magnessium carbonate $\left(\mathrm{MgCO}_{3}\right)$ or magnessium hydroxide $\left(\mathrm{Mg}(\mathrm{OH})_{2}\right)$ in farmers' fields with soil $\mathrm{pH}$ of $<5.5$ is desirable to increase the current low soil $\mathrm{pH}[46,17]$.

The electrical conductivity (EC) of the studied fields in Bukoba, Missenyi and Biharamulo Districts (Table 5) was very low $\left(0.03-0.17 \mathrm{dS} \mathrm{m}^{-1}\right)[36,43,44,47]$. However, [36, 44] reported that the soils with EC value of $<1.7 \mathrm{dS} \mathrm{m}^{-1}$ ) are fovourable for crop growth and development as they cannot cause crop yield reduction while those with $\mathrm{EC}$ at the range from $5.9-10 \mathrm{dS} \mathrm{m}^{-1}$ can cause crop yield reduction up to $100 \%$. Therefore, according to [36, 44], the EC of soils of the fields were favourable for crop growth and development.

Table 5. Levels of some chemical properties and their ratings for the studied soils in Bukoba, Missenyi and Biharamulo Districts, Tanzania.

\begin{tabular}{|c|c|c|c|c|c|c|c|c|c|c|}
\hline District & Village & Soil sampling site & $\begin{array}{l}\text { Soil } \mathrm{pH}_{\mathrm{w}} \\
(1: 2.5)\end{array}$ & $\begin{array}{l}\mathrm{EC}(\mathrm{dS} \\
\left.\mathrm{m}^{-1}\right)\end{array}$ & OC (\%) & $\begin{array}{l}\text { OM } \\
(\%)\end{array}$ & TN (\%) & $\mathrm{C}: \mathrm{N}$ ratio & $\begin{array}{l}\text { Bray - 1 P } \\
\left(\mathrm{mg} \mathrm{kg}^{-1}\right)\end{array}$ & $\begin{array}{l}\mathrm{SO}_{4}-\mathrm{S} \text { (mg } \\
\left.\mathrm{kg}^{-1}\right)\end{array}$ \\
\hline \multirow[t]{11}{*}{ Bukoba } & \multirow[t]{6}{*}{ Butairuka } & Rushabirwa farm & $5.1 \mathrm{sta}$ & $0.04 \mathrm{vl}$ & $2.93 \mathrm{~h}$ & $5.04 \mathrm{~h}$ & $0.24 \mathrm{~m}$ & $12 \mathrm{gq}$ & 6.311 & $5.21 \mathrm{~m}$ \\
\hline & & Mpanju farm & $5.1 \mathrm{sta}$ & $0.03 \mathrm{vl}$ & $3.16 \mathrm{~h}$ & $5.44 \mathrm{~h}$ & $0.26 \mathrm{~m}$ & $12 \mathrm{gq}$ & $7.42 \mathrm{~m}$ & $10.42 \mathrm{~m}$ \\
\hline & & Kahigi farm & $5.2 \mathrm{sta}$ & $0.04 \mathrm{vl}$ & $2.54 \mathrm{~h}$ & $4.37 \mathrm{~h}$ & $0.23 \mathrm{~m}$ & $11 \mathrm{gq}$ & $8.04 \mathrm{~m}$ & $8.33 \mathrm{~m}$ \\
\hline & & Bana farm & $5.4 \mathrm{sta}$ & $0.04 \mathrm{vl}$ & $2.93 \mathrm{~h}$ & $5.04 \mathrm{~h}$ & $0.22 \mathrm{~m}$ & $13 \mathrm{gq}$ & $11.51 \mathrm{~m}$ & $10.07 \mathrm{~m}$ \\
\hline & & Kyabitara farm & $5.4 \mathrm{sta}$ & $0.08 \mathrm{vl}$ & $3.90 \mathrm{vh}$ & $6.71 \mathrm{vh}$ & $0.28 \mathrm{~m}$ & $14 \mathrm{mq}$ & 5.101 & $9.03 \mathrm{~m}$ \\
\hline & & TARI Maruku Centre & $5.1 \mathrm{sta}$ & $0.05 \mathrm{vl}$ & $3.10 \mathrm{~h}$ & $5.33 \mathrm{~h}$ & $0.41 \mathrm{~m}$ & $8 \mathrm{gq}$ & 1.381 & $7.88 \mathrm{~m}$ \\
\hline & \multirow[t]{5}{*}{ Kiilima } & Degratias farm & $5.1 \mathrm{sta}$ & $0.07 \mathrm{vl}$ & $3.00 \mathrm{~h}$ & $5.16 \mathrm{~h}$ & $0.28 \mathrm{~m}$ & $11 \mathrm{gq}$ & $12.18 \mathrm{~m}$ & 4.511 \\
\hline & & Ifunya farm & $5.1 \mathrm{sta}$ & $0.05 \mathrm{vl}$ & $4.10 \mathrm{vh}$ & $7.05 \mathrm{vh}$ & $0.29 \mathrm{~m}$ & $14 \mathrm{mq}$ & 2.551 & $7.54 \mathrm{~m}$ \\
\hline & & Baguma farm & $5.1 \mathrm{sta}$ & $0.03 \mathrm{vl}$ & $5.61 \mathrm{vh}$ & $9.65 \mathrm{vh}$ & $0.41 \mathrm{~m}$ & $14 \mathrm{mq}$ & 2.561 & 3.471 \\
\hline & & Respicius farm & $5.1 \mathrm{sta}$ & $0.05 \mathrm{vl}$ & $3.90 \mathrm{vh}$ & $6.71 \mathrm{vh}$ & $0.29 \mathrm{~m}$ & $13 \mathrm{gq}$ & 3.171 & $5.68 \mathrm{~m}$ \\
\hline & & Godwin farm & $5.7 \mathrm{ma}$ & $0.05 \mathrm{vl}$ & $2.92 \mathrm{~h}$ & $5.02 \mathrm{~h}$ & $0.28 \mathrm{~m}$ & $10 \mathrm{gq}$ & $19.67 \mathrm{~m}$ & $9.54 \mathrm{~m}$ \\
\hline \multirow[t]{10}{*}{ Missenyi } & \multirow[t]{4}{*}{ Igayaza } & Farmers Extension Centre & $5.4 \mathrm{sta}$ & $0.05 \mathrm{vl}$ & $2.15 \mathrm{~m}$ & $3.70 \mathrm{~m}$ & 0.131 & $17 \mathrm{mq}$ & $75.44 \mathrm{~h}$ & $12.14 \mathrm{~m}$ \\
\hline & & Masood farm & $5.3 \mathrm{sta}$ & $0.04 \mathrm{vl}$ & $2.06 \mathrm{~m}$ & $3.54 \mathrm{~m}$ & 0.131 & $16 \mathrm{mq}$ & $29.49 \mathrm{~h}$ & $11.14 \mathrm{~m}$ \\
\hline & & Rubega farm & $5.8 \mathrm{ma}$ & $0.06 \mathrm{vl}$ & $2.23 \mathrm{~m}$ & $3.84 \mathrm{~m}$ & 0.181 & $12 \mathrm{gq}$ & $86.44 \mathrm{~h}$ & $6.43 \mathrm{~m}$ \\
\hline & & Tautus farm & $5.2 \mathrm{sta}$ & $0.03 \mathrm{vl}$ & $2.01 \mathrm{~m}$ & $3.46 \mathrm{~m}$ & 0.121 & $17 \mathrm{mq}$ & $30.61 \mathrm{~h}$ & $7.07 \mathrm{~m}$ \\
\hline & \multirow[t]{6}{*}{ Mabuye } & Mhonge farm & $5.6 \mathrm{ma}$ & $0.17 \mathrm{vl}$ & $1.76 \mathrm{~m}$ & $3.03 \mathrm{~m}$ & 0.161 & $11 \mathrm{gq}$ & $21.91 \mathrm{~h}$ & 3.991 \\
\hline & & Maida farm & $5.7 \mathrm{ma}$ & $0.07 \mathrm{vl}$ & $1.95 \mathrm{~m}$ & $3.35 \mathrm{~m}$ & 0.191 & $10 \mathrm{gq}$ & $29.74 \mathrm{~h}$ & 2.861 \\
\hline & & Mabuye society & $5.6 \mathrm{ma}$ & $0.05 \mathrm{vl}$ & $1.32 \mathrm{~m}$ & $2.27 \mathrm{~m}$ & 0.151 & $9 \mathrm{gq}$ & $37.26 \mathrm{~h}$ & 2.711 \\
\hline & & Pascal farm & $5.8 \mathrm{ma}$ & $0.07 \mathrm{vl}$ & $1.91 \mathrm{~m}$ & $3.29 \mathrm{~m}$ & 0.181 & $11 \mathrm{gq}$ & $26.96 \mathrm{~h}$ & 4.171 \\
\hline & & Gervas farm & $6.1 \mathrm{sa}$ & $0.07 \mathrm{vl}$ & $1.26 \mathrm{~m}$ & $2.17 \mathrm{~m}$ & 0.111 & $11 \mathrm{gq}$ & $51.85 \mathrm{~h}$ & 3.621 \\
\hline & & Mabuye Primary School & $6.0 \mathrm{~m}$ & 0.06 & $1.30 \mathrm{~m}$ & $2.24 \mathrm{~m}$ & 0.131 & $8 \mathrm{gq}$ & $35.32 \mathrm{~h}$ & 3.211 \\
\hline \multirow[t]{9}{*}{ Biharamulo } & \multirow[t]{5}{*}{ Rukirwengama } & Edmund farm & $5.9 \mathrm{ma}$ & $0.04 \mathrm{vl}$ & 0.981 & 1.691 & $0.05 \mathrm{vl}$ & $20 \mathrm{mq}$ & 3.411 & 3.931 \\
\hline & & Benjamin farm & $5.1 \mathrm{sta}$ & $0.03 \mathrm{vl}$ & 0.721 & 1.241 & $0.04 \mathrm{vl}$ & $18 \mathrm{mq}$ & 1.391 & $8.93 \mathrm{~m}$ \\
\hline & & Chubwa farm & $5.5 \mathrm{sta}$ & $0.03 \mathrm{vl}$ & 0.651 & 1.121 & $0.04 \mathrm{vl}$ & $16 \mathrm{mq}$ & 1.971 & 3.931 \\
\hline & & Wilson farm & $6.1 \mathrm{sa}$ & $0.03 \mathrm{vl}$ & 0.731 & 1.261 & $0.05 \mathrm{vl}$ & $15 \mathrm{mq}$ & 6.041 & $6.67 \mathrm{~m}$ \\
\hline & & Mtanzania farm & $5.2 \mathrm{sta}$ & $0.04 \mathrm{vl}$ & 0.961 & 1.651 & $0.06 \mathrm{vl}$ & $16 \mathrm{mq}$ & 1.671 & $9.57 \mathrm{~m}$ \\
\hline & \multirow[t]{4}{*}{ Rukaragata } & Yustina farm & $5.3 \mathrm{sta}$ & $0.03 \mathrm{vl}$ & $1.37 \mathrm{~m}$ & $2.36 \mathrm{~m}$ & $0.08 \mathrm{vl}$ & $17 \mathrm{mq}$ & 4.561 & $6.93 \mathrm{~m}$ \\
\hline & & Chinga farm & $5.6 \mathrm{ma}$ & $0.03 \mathrm{vl}$ & $1.72 \mathrm{~m}$ & $2.96 \mathrm{~m}$ & $0.07 \mathrm{vl}$ & $25 \mathrm{pq}$ & 0.441 & $8.21 \mathrm{~m}$ \\
\hline & & Mutalemwa farm & $5.7 \mathrm{ma}$ & $0.03 \mathrm{vl}$ & $1.76 \mathrm{~m}$ & $3.03 \mathrm{~m}$ & $0.08 \mathrm{vl}$ & $22 \mathrm{pq}$ & 1.101 & $6.76 \mathrm{~m}$ \\
\hline & & Farmers Extension Centre & $5.4 \mathrm{sta}$ & $0.03 \mathrm{vl}$ & 1.201 & 2.061 & 0.181 & $7 \mathrm{gq}$ & 4.961 & $6.32 \mathrm{~m}$ \\
\hline
\end{tabular}

Chemical property: $\mathrm{EC}=$ electric conductivity; $\mathrm{OC}=$ organic carbon; $\mathrm{TN}=$ total nitrogen; $\mathrm{C}: \mathrm{N}=$ carbon: nitrogen ratio; $\mathrm{Bray}-1 \mathrm{P}=\mathrm{Bray}-1$ phosphorus; $\mathrm{SO}{ }_{4}$ $\mathrm{S}=$ sulphate-sulpur.

Rating: sta=strong acid; ma=moderate acid; sa=slightly acid; $\mathrm{l}=\mathrm{low}$; vl=very low; $\mathrm{h}=$ high; vh=very high; $\mathrm{m}=\mathrm{medium}$; gq=good quality; mq=moderate quality; $\mathrm{pq}=$ poor quality. 


\subsubsection{Organic Carbon, Total Nitrogen and Carbon- Nitrogen Ratio}

The soil organic carbon of the studied fields in Bukoba District ranged from high (2.54\%) to very high $(5.61 \%)$ (Table 5). In Missenyi District, it ranged from low (1.01\%) to high $(2.73 \%)$ while in Biharamulo District it ranged from low $(0.65 \%)$ to medium (1.76\%) [36, 41-44]. In Bukoba District, about $55 \%$ and $45 \%$ of the studied fields had very high and high OC, respectively, while in Missenyi District, about 91\% and $9 \%$ of the studied fields had medium and high OC, respectively. In Biharamulo District, about $45 \%$ of the fields had medium OC and 55\% had low OC (Table 3). The low $\mathrm{OC}$ in some fields in Biharamulo District may be due to poor management of organic matter caused by poor farming practices deployed by farmers, such as crop residues removal after harvesting and bush burning during land preparation [22, $3]$.

Total nitrogen (TN) of the studied fields was medium $(0.22$ - $0.41 \%)$ in Bukoba District, low (0.11 - 0.19\%) in Missenyi District and very low $(0.04 \%)$ to low $(0.18 \%)$ in Biharamulo District [36, 41-44]. The low to very low levels of TN in Missenyi and Biharamulo Districts may be due to the medium and low levels of OC in those fields (Table 5). Other researchers [48] reported that soil organic matter (SOM) is a primary source of nitrogen in the soil. However, [47] reported that SOM content is not a quantitative indicator of the capacity of soil to supply nitrogen for plant growth; even though the soils may have high SOM content but the time and amount of nitrogen released from the soil organic matter depend on soil temperature, moisture, microbial activity and many other soil management factors.

The carbon-nitrogen ratio ( $\mathrm{C}: \mathrm{N}$ ratio) of the soil is an indication of the quality of organic matter present in the soil [44]. The C:N ratio of the studied farmers' fields in Bukoba District ranged from good quality (8) to medium quality (14). In Missenyi District, it ranged from good quality (8) to medium quality (17) while in Biharamulo District it ranged from good quality (7) to poor quality (25) [42, 36, 44, 49]. In Bukoba District, about $73 \%$ and $27 \%$ of the studied fields had good quality and medium quality $\mathrm{C}: \mathrm{N}$ ratios, respectively, while in Missenyi District, about $64 \%$ and $56 \%$ of the studied fields had good quality and medium $\mathrm{C}: \mathrm{N}$ ratios, respectively. Moreover, in Biharamulo District, about 9\%, 73\% and 18\% of the studied fields had good, medium and poor quality C:N ratios, respectively (Table 5). Good quality $\mathrm{C}: \mathrm{N}$ ratios of some fields in the study area was an indication of the presence of good quality organic matter, leading to high decomposition rate by soil microbes thereby leading to nutrient release into the soils $[50,17]$ and the opposite occurs due to the presence of poor quality organic matter. Therefore, planting of legume cover crops such Mucuna pruriens, Tephrosia vogelii and Lablab [22] and green manure crops such as Leucaena spp, Tithonia diversifolia, alfalfa and pea (Pisum sativum) followed by incorporation into the soil [3] in those fields with poor quality organic matter is desirable for improving the $\mathrm{C}: \mathrm{N}$ ratio of the soils.

\subsubsection{Extractable Phosphorus and Sulphur}

The extractable phosphorus (P) of the studied fields in Bukoba District ranged from low $\left(1.38 \mathrm{mg} \mathrm{kg}^{-1}\right)$ to medium (19.67 mg kg-1). In Missenyi and Biharamulo Districts Extractable P was high (21.91 - $\left.75.44 \mathrm{mg} \mathrm{kg}^{-1}\right)$ and low (0.44 - $6.04 \mathrm{mg} \mathrm{kg}^{-1}$ ), respectively [42-44, 47, 49] (Table 5). The low to medium levels of extractable $\mathrm{P}$ in the fields in Bukoba and Biharamulo Districts may be attributed to the low inherent $\mathrm{P}$ in the parent materials developed mainly on basement rocks of granite, quartzite and shale [51, 13, 45]. It may also be due to low soil $\mathrm{pH}$ that normally favours reaction with iron ( $\mathrm{Fe}$ ) and aluminium (Al) to inhibit the availability of $\mathrm{P}$ into the soil for plant uptake due to $\mathrm{P}$ fixation $[36,52,17$, $45,53]$. According to [36], plant response to applied $P$ could be expected when soil available $\mathrm{P}$ is less than $15 \mathrm{mg} \mathrm{kg}^{-1}$ soil. Therefore, the use of inorganic P fertilizers such TSP, SSP and DAP and organic fertilizers such manure, compost and incorporation of green manure crops and crop residues [3] into those soils with low available $\mathrm{P}$ is desirable, to improve soil P levels. Appropriate uses of organic resources also improve soil $\mathrm{pH}$ levels hence, enhancing the availability of fixed $\mathrm{P}$ in the soils [17].

The sulphate sulphur $\left(\mathrm{SO}_{4}-\mathrm{S}\right)$ levels of the studied fields ranged from low levels of $3.47,2.71$ and $3.71 \mathrm{mg} \mathrm{kg}^{-1}$ in Bukoba, Missenyi and Biharamulo Districts, respectively to medium levels of 10.07, 12.14 and $9.57 \mathrm{mg} \mathrm{kg}^{-1}$ in Bukoba, Missenyi and Biharamulo Districts, respectively [47] (Table 5). In Bukoba District, about $18 \%$ and $82 \%$ of the studied fields had low and medium $\mathrm{SO}_{4}-\mathrm{S}$, respectively. In Missenyi District, about $54 \%$ and $46 \%$ of the studied fields had low and medium levels of extractable $\mathrm{SO}_{4}$-S. In Biharamulo District about, 46 and 54\% of the fields had low and medium levels extractable $\mathrm{SO}_{4}$-S. However, [36] reported that in most tropical soils a sulphur content of $6 \mathrm{mg} \mathrm{kg}^{-1}$ is the critical level, below which response of most tropical crops is expected. Therefore, according to [36], about $36.4 \%$ of the studied fields in the study area had inadequate levels of sulphur, hence sulphur-containing fertilizers such as magnesium sulphate $\left(\mathrm{MgSO}_{4}\right)$, potassium sulphate $\left(\mathrm{K}_{2} \mathrm{SO}_{4}\right)$ or ammonium sulphate $\left(\left(\mathrm{NH}_{4}\right)_{2} \mathrm{SO}_{4}\right)$ are desirable in those fields at the recommended rate for optimal and sustainable crop yields.

\subsubsection{Exchangeable Bases}

Exchangeable calcium $\left(\mathrm{Ca}^{2+}\right)$ of the studied fields (Table 6) in Bukoba District ranged from low $\left(2.30 \mathrm{cmol}(+) \mathrm{kg}^{-1}\right)$ to medium $\left(3.80 \mathrm{cmol}(+) \mathrm{kg}^{-1}\right)$ and from low $\left(2.30 \mathrm{cmol}(+) \mathrm{kg}^{-1}\right)$ to high $\left(10.80 \mathrm{cmol}(+) \mathrm{kg}^{-1}\right)$ in Missenyi District. In Biharamulo District, it ranged from medium $(2.80 \mathrm{cmol}(+)$ $\left.\mathrm{kg}^{-1}\right)$ to high $\left(6.80 \mathrm{cmol}(+) \mathrm{kg}^{-1}\right)$ [41-44, 47, 49]. In Bukoba District, about $28 \%$ and $72 \%$ of the fields had low and medium exchangeable $\mathrm{Ca}$, respectively while in Missenyi District, about $27 \%$ and $73 \%$ of the fields had low and high exchangeable Ca, respectively. In Biharamulo District, about $73 \%$ and $27 \%$ of the fields had medium and high exchangeable $\mathrm{Ca}$, respectively. 
Exchangeable magnessium $\left(\mathrm{Mg}^{2+}\right)$ of the studied fields in Bukoba District ranged from low $\left(0.44 \mathrm{cmol}(+) \mathrm{kg}^{-1}\right)$ to medium $\left(1.07 \mathrm{cmol}(+) \mathrm{kg}^{-1}\right)$ and from medium $(1.40 \mathrm{cmol}(+)$ $\left.\mathrm{kg}^{-1}\right)$ to very high $\left(4.35 \mathrm{cmol}(+) \mathrm{kg}^{-1}\right)$ in Missenyi District. In Biharamulo District, it ranged from medium $(1.33 \mathrm{cmol}(+)$ $\left.\mathrm{kg}^{-1}\right)$ to very high $\left(3.98 \mathrm{cmol}(+) \mathrm{kg}^{-1}\right)$ [41-44, 47, 49]. In Bukoba District, about $64 \%$ and $36 \%$ of the fields had low and medium exchangeable $\mathrm{Mg}$, respectively, while in Missenyi District, about $9 \%, 64 \%$ and $27 \%$ of the fields had medium, high and very high exchangeable $\mathrm{Mg}$, respectively. In Biharamulo District, about $36 \%, 18 \%$ and $46 \%$ of the fields had medium, high and very high exchangeable $\mathrm{Mg}$, respectively.

Exchangeable potassium $\left(\mathrm{K}^{+}\right)$of the studied fields in Bukoba District ranged from very low $\left(0.08 \mathrm{cmol}(+) \mathrm{kg}^{-1}\right)$ to low $\left(0.18 \mathrm{cmol}(+) \mathrm{kg}^{-1}\right)$ and from low $\left(0.24 \mathrm{cmol}(+) \mathrm{kg}^{-1}\right)$ to medium $\left(0.98 \mathrm{cmol}(+) \mathrm{kg}^{-1}\right)$ in Missenyi District. In Biharamulo District, it ranged from very low $(0.09 \mathrm{cmol}(+)$ $\left.\mathrm{kg}^{-1}\right)$ to medium $\left(0.42 \mathrm{cmol}(+) \mathrm{kg}^{-1}\right)$ [41-44, 47, 49] (Table 6).
In Bukoba District, about $64 \%$ and $36 \%$ of the fields had very low and low exchangeable $\mathrm{K}$, respectively, while in Missenyi District, about $18 \%$ and $82 \%$ of the fields had low and medium exchangeable $\mathrm{K}$, respectively. In Biharamulo District, about $36 \%, 55 \%$ and $9 \%$ of the fields had very low, low and medium exchangeable $\mathrm{K}$, respectively.

Exchangeable sodium $\left(\mathrm{Na}^{+}\right)$of the studied fields in Bukoba District was very low $\left(0.04-0.09 \operatorname{cmol}(+) \mathrm{kg}^{-1}\right)$ and ranged from very low $\left(0.05 \mathrm{cmol}(+) \mathrm{kg}^{-1}\right)$ to low $(0.18$ cmol(+) $\left.\mathrm{kg}^{-1}\right)$ in Missenyi District. In Biharamulo District, it ranged from very low $\left(0.04 \mathrm{cmol}(+) \mathrm{kg}^{-1}\right)$ to low $(0.14$ cmol(+) $\mathrm{kg}^{-1}$ ) [43, 44, 47, 49] (Table 6). In Bukoba District, all $(100 \%)$ studied fields had very low exchangeable $\mathrm{Na}$ while in Missenyi District, about $45.5 \%, 45.5 \%$ and $9 \%$, of the fields had very low, low and medium exchangeable $\mathrm{Na}$, respectively. In Biharamulo District, about $82 \%$ and $18 \%$ of the fields had very low and low exchangeable $\mathrm{Na}$, respectively, which signify no sodicity problem in the studied fields $[36,45]$.

Table 6. Exchangeable bases and cation exchange capacity levels and ratings of the studied soils in Bukoba, Missenyi and Biharamulo Districts, Tanzania

\begin{tabular}{|c|c|c|c|c|c|c|c|c|c|}
\hline \multirow{2}{*}{ District } & \multirow{2}{*}{ Village } & \multirow{2}{*}{ Soil sampling site } & $\mathrm{Ca}$ & Mg & $\mathbf{K}$ & $\mathrm{Na}$ & CEC & ESP & BS \\
\hline & & & \multicolumn{5}{|c|}{$\mathrm{Cmol}(+) \mathrm{kg}^{-1}$} & \multicolumn{2}{|l|}{$\%$} \\
\hline \multirow[t]{11}{*}{ Bukoba } & \multirow[t]{6}{*}{ Butairuka } & Rushabirwa farm & $3.80 \mathrm{~m}$ & $1.07 \mathrm{~m}$ & $0.08 \mathrm{vl}$ & $0.05 \mathrm{vl}$ & $5.80 \mathrm{vl}$ & $0.86 \mathrm{nsd}$ & $86.21 \mathrm{~h}$ \\
\hline & & Mpanju farm & $3.30 \mathrm{~m}$ & $1.04 \mathrm{~m}$ & $0.09 \mathrm{vl}$ & $0.08 \mathrm{vl}$ & 7.601 & $1.05 \mathrm{nsd}$ & $59.34 \mathrm{~m}$ \\
\hline & & Kahigi farm & $3.80 \mathrm{~m}$ & 0.721 & $0.12 \mathrm{vl}$ & $0.06 \mathrm{vl}$ & 7.401 & $0.81 \mathrm{nsd}$ & $63.51 \mathrm{~h}$ \\
\hline & & Bana farm & $3.80 \mathrm{~m}$ & 0.681 & $0.09 \mathrm{vl}$ & $0.05 \mathrm{vl}$ & 6.201 & $0.81 \mathrm{nsd}$ & $74.52 \mathrm{~h}$ \\
\hline & & Kyabitara farm & $3.30 \mathrm{~m}$ & 0.531 & 0.131 & $0.07 \mathrm{vl}$ & 7.001 & $1.00 \mathrm{nsd}$ & $57.57 \mathrm{~m}$ \\
\hline & & TARI Maruku & $2.90 \mathrm{~m}$ & 0.441 & 0.151 & $0.09 \mathrm{vl}$ & $20.60 \mathrm{~m}$ & $0.44 \mathrm{nsd}$ & 12.821 \\
\hline & \multirow{5}{*}{ Kiilima } & Degratias farm & 2.301 & 0.641 & 0.181 & $0.05 \mathrm{vl}$ & $13.00 \mathrm{~m}$ & $0.38 \mathrm{nsd}$ & $24.38 \mathrm{~m}$ \\
\hline & & Ifunya farm & $2.80 \mathrm{~m}$ & 0.751 & $0.12 \mathrm{vl}$ & $0.08 \mathrm{vl}$ & $15.20 \mathrm{~m}$ & $0.53 \mathrm{nsd}$ & $24.67 \mathrm{~m}$ \\
\hline & & Baguma farm & 2.301 & 0.721 & 0.141 & $0.09 \mathrm{vl}$ & $16.80 \mathrm{~m}$ & $0.54 \mathrm{nsd}$ & 19.351 \\
\hline & & Respicius farm & $2.80 \mathrm{~m}$ & $1.06 \mathrm{~m}$ & $0.11 \mathrm{vl}$ & $0.09 \mathrm{vl}$ & 11.291 & $0.80 \mathrm{nsd}$ & $35.96 \mathrm{~m}$ \\
\hline & & Godwin farm & 2.301 & $0.95 \mathrm{~m}$ & $0.09 \mathrm{vl}$ & $0.04 \mathrm{vl}$ & 11.001 & $0.36 \mathrm{nsd}$ & $30.73 \mathrm{~m}$ \\
\hline \multirow[t]{11}{*}{ Missenyi } & \multirow[t]{5}{*}{ Igayaza } & Extension Centre & 2.301 & $2.34 \mathrm{~h}$ & 0.241 & $0.08 \mathrm{vl}$ & $13.20 \mathrm{~m}$ & $0.61 \mathrm{nsd}$ & $37.58 \mathrm{~m}$ \\
\hline & & Masood farm & $2.80 \mathrm{~m}$ & $2.28 \mathrm{~h}$ & 0.251 & $0.10 \mathrm{vl}$ & $16.80 \mathrm{~m}$ & $0.60 \mathrm{nsd}$ & $32.32 \mathrm{~m}$ \\
\hline & & Kaloli farm & 2.301 & $4.35 \mathrm{vh}$ & $0.60 \mathrm{~m}$ & 0.091 & $17.20 \mathrm{~m}$ & $0.52 \mathrm{nsd}$ & $42.67 \mathrm{~m}$ \\
\hline & & Rubega farm & $2.80 \mathrm{~m}$ & $3.13 \mathrm{vh}$ & $0.36 \mathrm{~m}$ & 0.111 & $17.20 \mathrm{~m}$ & $0.64 \mathrm{nsd}$ & $37.21 \mathrm{~m}$ \\
\hline & & Tautus farm & 2.301 & $2.69 \mathrm{~h}$ & $0.30 \mathrm{~m}$ & $0.07 \mathrm{vl}$ & $14.40 \mathrm{~m}$ & $0.49 \mathrm{nsd}$ & $37.22 \mathrm{~m}$ \\
\hline & \multirow[t]{6}{*}{ Mabuye } & Mhonge farm & $7.80 \mathrm{~h}$ & $2.75 \mathrm{~h}$ & $0.98 \mathrm{~m}$ & 0.111 & $23.00 \mathrm{~m}$ & $0.48 \mathrm{nsd}$ & $50.61 \mathrm{~m}$ \\
\hline & & Maida farm & $7.80 \mathrm{~h}$ & $3.11 \mathrm{vh}$ & $0.47 \mathrm{~m}$ & 0.131 & $18.00 \mathrm{~m}$ & $0.72 \mathrm{nsd}$ & $63.94 \mathrm{~h}$ \\
\hline & & Mabuye society & $6.30 \mathrm{~h}$ & $2.26 \mathrm{~h}$ & $0.37 \mathrm{~m}$ & $0.07 \mathrm{vl}$ & $13.20 \mathrm{~m}$ & $0.53 \mathrm{nsd}$ & $68.18 \mathrm{~h}$ \\
\hline & & Pascal farm & $10.8 \mathrm{~h}$ & $2.01 \mathrm{~h}$ & $0.67 \mathrm{~m}$ & 0.181 & $19.80 \mathrm{~m}$ & $0.91 \mathrm{nsd}$ & $68.99 \mathrm{~h}$ \\
\hline & & Gervas farm & $9.80 \mathrm{~h}$ & $2.15 \mathrm{~h}$ & $0.59 \mathrm{~m}$ & $0.05 \mathrm{vl}$ & $16.12 \mathrm{~m}$ & $0.31 \mathrm{nsd}$ & $78.10 \mathrm{~h}$ \\
\hline & & Mabuye Primary & $5.80 \mathrm{~h}$ & $1.40 \mathrm{~m}$ & $0.51 \mathrm{~m}$ & $0.58 \mathrm{~m}$ & 7.601 & $7.63 \mathrm{slsd}$ & $109.08 \mathrm{~h}$ \\
\hline \multirow[t]{11}{*}{ Biharamulo } & \multirow[t]{5}{*}{ Rukirwengama } & Edmund farm & $4.80 \mathrm{~m}$ & $2.76 \mathrm{~h}$ & 0.161 & 0.141 & 8.001 & $1.75 \mathrm{nsd}$ & $98.25 \mathrm{~h}$ \\
\hline & & Benjamin farm & $2.80 \mathrm{~m}$ & $1.33 \mathrm{~m}$ & $0.10 \mathrm{vl}$ & 0.101 & $5.20 \mathrm{vl}$ & $1.92 \mathrm{nsd}$ & $83.27 \mathrm{~h}$ \\
\hline & & Chubwa farm & $3.30 \mathrm{~m}$ & $1.41 \mathrm{~m}$ & $0.09 \mathrm{vl}$ & $0.06 \mathrm{vl}$ & 6.601 & $0.91 \mathrm{nsd}$ & $73.64 \mathrm{~h}$ \\
\hline & & Wilson farm & $3.30 \mathrm{~m}$ & $1.49 \mathrm{~m}$ & $0.10 \mathrm{vl}$ & $0.04 \mathrm{vl}$ & 6.201 & $0.65 \mathrm{nsd}$ & $79.52 \mathrm{~h}$ \\
\hline & & Mtanzania farm & $2.80 \mathrm{~m}$ & $2.46 \mathrm{~h}$ & $0.10 \mathrm{vl}$ & $0.05 \mathrm{vl}$ & 8.001 & $0.63 \mathrm{nsd}$ & $67.63 \mathrm{~h}$ \\
\hline & \multirow[t]{6}{*}{ Rukaragata } & Yustina farm & $7.30 \mathrm{~h}$ & $3.60 \mathrm{vh}$ & $0.42 \mathrm{~m}$ & $0.06 \mathrm{vl}$ & $14.60 \mathrm{~m}$ & $0.41 \mathrm{nsd}$ & $77.95 \mathrm{~h}$ \\
\hline & & Chinga farm & $6.30 \mathrm{~h}$ & $3.98 \mathrm{vh}$ & 0.201 & $0.07 \mathrm{vl}$ & $15.20 \mathrm{~m}$ & $0.46 \mathrm{nsd}$ & $69.41 \mathrm{~h}$ \\
\hline & & Mkanirwa farm & $6.80 \mathrm{~m}$ & $3.13 \mathrm{vh}$ & 0.331 & $0.05 \mathrm{vl}$ & 11.801 & $0.42 \mathrm{nsd}$ & $87.37 \mathrm{~h}$ \\
\hline & & Village Office & $5.20 \mathrm{~m}$ & $3.01 \mathrm{vh}$ & 0.201 & $0.06 \mathrm{vl}$ & 12.001 & $0.50 \mathrm{nsd}$ & $70.58 \mathrm{~h}$ \\
\hline & & Mutalemwa farm & $6.80 \mathrm{~h}$ & $3.44 \mathrm{vh}$ & 0.201 & $0.04 \mathrm{vl}$ & $15.00 \mathrm{~m}$ & $0.27 \mathrm{nsd}$ & $69.87 \mathrm{~h}$ \\
\hline & & Extension Centre & $4.75 \mathrm{~m}$ & $1.57 \mathrm{~m}$ & 0.161 & $0.07 \mathrm{vl}$ & $15.40 \mathrm{~m}$ & $0.45 \mathrm{nsd}$ & $42.53 \mathrm{~m}$ \\
\hline
\end{tabular}

Chemical property: $\mathrm{Ca}=$ calcium, $\mathrm{Mg}=$ magnessium, $\mathrm{K}=$ potassium, $\mathrm{Na}=$ sodium $\mathrm{CEC}=$ cation exchange capacity, $\mathrm{ESP}=$ exchangeable sodium percentage, $\mathrm{BS}=$ base saturation.

Rating: $\mathrm{l}=$ low; $\mathrm{vl}=$ very low; $\mathrm{h}=$ high; vh=very high; $\mathrm{m}=$ =medium, gq; $\mathrm{nsd}=$ non sodic.

The low levels of exchangeable bases in some studied fields in the study area were attributed to low soil $\mathrm{pH}$. Other researchers [47] reported that calcium deficiency usually occurs on very acidic soils with low organic matter. Another reason may be the nature of parent materials being dominated by shales and quartzite, which are aluminous, siliceous and 
ferruginous with low levels of soluble bases [51, 13]. In addition, leaching of soluble bases such as $\mathrm{K}$ and $\mathrm{Mg}$ occurs due to high rainfall $[22,17]$ predominantly in Bukoba and Missenyi, which receive annual rainfall ranging from 1100 $\mathrm{mm}$ to $>2500 \mathrm{~mm}[19,20]$.

The soil with low exchangeable bases may lead to plant nutrient imbalances, unavailability and nutrient induced deficiencies [54, 45]. However, this study indicated that in all studied fields, exchangeable $\mathrm{K}$ was more limiting nutrients than other exchangeable bases, as $70 \%$ of the studied fields had low to very low levels of exchangeable $\mathrm{K}$. The low levels of exchangeable $\mathrm{K}$ in soils affect crop growth and development. Potassium plays a major cationic role in the plants and is therefore, regarded as an essential element to plant life [55]. Plants cannot survive without its presence due to its importance in controlling many physiological processes, such as photosynthesis, enzyme activation, transportation of metabolites and water protein synthesis as well as improving plant growth, development and yields [56]. Adequate level of exchangeable $\mathrm{K}$ in soil for plant uptake, also help to minimize the risk of drought stress in plants as it control the process of opening and closing of stomata in [57]. Therefore, use K-containing fertilizers such as muriate of potash $(\mathrm{KCl})$ sulphate of potash $\left(\mathrm{K}_{2} \mathrm{SO}_{4}\right)$, potassium nitrate $\left(\mathrm{KNO}_{3}\right)$ or potassium meta-phosphate $\left(\mathrm{KPO}_{3}\right)$ together with manure or/and compost, is desirable in those fields with low levels of exchangeable $\mathrm{K}$ for improving $\mathrm{K}$ levels in the soils.

\subsubsection{Cation Exchange Capacity, Percent Base Saturation and Exchangeable Sodium Percentage}

The fertility status of the soil is reflected by its cation exchange capacity (CEC), and higher CEC values reflect higher soil fertility [58]. The CEC of the studied fields in Bukoba District ranged from very low $\left(5.80 \mathrm{cmol}(+) \mathrm{kg}^{-1}\right)$ to medium (16.80 cmol(+) $\left.\mathrm{kg}^{-1}\right)$ and from low $\left(7.60 \mathrm{cmol}(+) \mathrm{kg}^{-}\right.$ $\left.{ }^{1}\right)$ to medium $\left(23.00 \mathrm{cmol}(+) \mathrm{kg}^{-1}\right)$ in Missenyi District. In Biharamulo District, it ranged from very low $(5.20 \mathrm{cmol}(+)$ $\left.\mathrm{kg}^{-1}\right)$ to medium $\left(15.40 \mathrm{cmol}(+) \mathrm{kg}^{-1}\right)[44,47,49]$ (Table 6). In Bukoba District, about $9 \%, 55 \%$ and $36 \%$ of the fields had very low, low and medium $\mathrm{CEC}$, respectively, while in Missenyi District, all the studied fields had medium CEC. In Biharamulo District, about $9 \%, 55 \%$ and $36 \%$ of the fields had very low, low and medium CEC. The low levels of CEC in some fields in the study area may be due to low organic matter content in the soils.

The percentage base saturation (BS) of the studied fields in Bukoba District ranged from low (12.86\%) to high (86.21\%) and it ranged from medium (32.32\%) to high (109.08\%) in Missenyi District. In Biharamulo District, BS was high $(42.53-98.25 \%)$ in all studied fields [36]. In Bukoba District, about $18 \%, 55 \%$ and $27 \%$ of the fields had low, medium and high BS, respectively, while in Missenyi District about $60 \%$ and $40 \%$ of the studied fields had medium and high BS, respectively. In Biharamulo District, all studied fields had high BS (Table 6). The low level of BS in some fields in Bukoba District may be attributed to high rainfall $(>2500$ $\mathrm{mm}$ ) received annually $[22,20]$, which leads to leaching of soluble bases. However, [59] reported that BS value of $>50 \%$ is high and favourable for crop production whereas BS value of $<50 \%$ is low and less favourable for crop production. Low base saturation levels may result in very acid soils and may favour toxicity of cations like aluminium, iron and manganese $[36,60]$. Therefore, according to [59]; 55\%, 46\% and $9 \%$ of studied fields in Bukoba Missenyi and Biharamulo Districts, respectively were less favourable for crop growth and development. Hence, application of fertilizers containing soluble bases e.g. CAN, MOP or sulphate of potash is desirable to improve the levels of exchangeable bases in those soils. Exchangeable sodium percentage (ESP) of the studied fields ranged from 0.36 to $1.92 \%$, which according to $[36,43,44]$; the soils of the studied fields were non-sodic, hence favourable for crop growth and development.

\subsubsection{Extractable Micronutrients}

Extractable zinc $(\mathrm{Zn})$ of the studied fields (Table 7 ) in Bukoba District ranged from medium $\left(0.85 \mathrm{mg} \mathrm{kg}^{-1}\right)$ to high (6.95 $\left.\mathrm{mg} \mathrm{kg}^{-1}\right)$ and was high (4.89 - $\left.18.41 \mathrm{mg} \mathrm{kg}^{-1}\right)$ in Missenyi District. In Biharamulo District, extractable $\mathrm{Zn}$ ranged from medium $\left(1.93 \mathrm{mg} \mathrm{kg}^{-1}\right)$ to high $\left(3.69 \mathrm{mg} \mathrm{kg}^{-1}\right)$ in the studied fields [61-63]. In Bukoba District, about 55\% and $45 \%$ of the fields had medium and high extractable $\mathrm{Zn}$, respectively while in Missenyi District, about $9 \%$ and $91 \%$ of the fields had medium and high extractable $\mathrm{Zn}$, respectively. In Biharamulo District, about $18 \%$ and $82 \%$ of the fields had medium and high extractable $\mathrm{Zn}$, respectively. About $70 \%$ of the studied fields in the study area had high level of extractable $\mathrm{Zn}$. Therefore, proper management of $\mathrm{Zn}$ in those farmers' fields with high level of $\mathrm{Zn}$ is desirable, for example, proper or limited use of $\mathrm{Zn}$-based fungicide [64].

Extractable iron (Fe) of the studied fields was high, ranging from 19.50 - $444.64 \mathrm{mg} \mathrm{kg}^{-1}, 33.73$ - $473.21 \mathrm{mg} \mathrm{kg}^{-1}$ and 13.86 - $105.79 \mathrm{mg} \mathrm{kg}^{-1}$ in Bukoba, Missenyi and Biharamulo Districts, respectively [65, 61, 63]. Thus, all the studied fields had high levels of extractable Fe (Table 7). The high levels of extractable Fe in those fields were attributed to the nature of parent materials, being quartzite and shale, which are aluminous, siliceous and ferruginous with low magnesium and potassium content [51, 13]. However, [66] reported that Ferrous Fe concentrations of $>400 \mathrm{mg} \mathrm{kg}^{-1}$ in the soil during most of the season are associated with toxicity; therefore, management of $\mathrm{Fe}$ in those fields with $\mathrm{Fe}$ levels $>400 \mathrm{mg} \mathrm{kg}^{-1}$ is desired. For example, through combined use of organic fertilizers (farmyard manure, compost and/or crop residues) and inorganic fertilizers ( $\mathrm{P}$ and $\mathrm{K}$ fertilizers) to decrease Fe levels. Moreover, use of liming materials such as $\mathrm{CaCO}_{3}$ and $\mathrm{MgCO}_{3}$ to increase the $\mathrm{pH}$ of the soils in those fields with strongly acid soils. 
Table 7. Some micronutrients levels with their ratings of the studied fields in Bukoba, Missenyi and Biharamulo Districts, Tanzania.

\begin{tabular}{|c|c|c|c|c|c|c|}
\hline \multirow{2}{*}{ District } & \multirow{2}{*}{ Village } & \multirow{2}{*}{ Soil sampling site } & Zn & $\mathbf{F e}$ & Mn & $\mathbf{C u}$ \\
\hline & & & \multicolumn{4}{|l|}{$\mathrm{mg} \mathrm{kg}^{-1}$} \\
\hline \multirow[t]{11}{*}{ Bukoba } & \multirow[t]{5}{*}{ Butairuka } & Rushabirwa farm & $1.98 \mathrm{~m}$ & $326.79 \mathrm{~h}$ & $3.45 \mathrm{~m}$ & $2.34 \mathrm{~h}$ \\
\hline & & Mpanju farm & $1.05 \mathrm{~m}$ & $396.43 \mathrm{~h}$ & $3.64 \mathrm{~m}$ & $2.66 \mathrm{~h}$ \\
\hline & & Kahigi farm & $0.91 \mathrm{~m}$ & $356.93 \mathrm{~h}$ & $2.41 \mathrm{~m}$ & $1.88 \mathrm{~m}$ \\
\hline & & Bana farm & $0.85 \mathrm{~m}$ & $444.64 \mathrm{~h}$ & $3.97 \mathrm{~m}$ & $1.86 \mathrm{~m}$ \\
\hline & & Kyabitara farm & $1.48 \mathrm{~m}$ & $337.50 \mathrm{~h}$ & $2.93 \mathrm{~m}$ & $2.81 \mathrm{~h}$ \\
\hline & \multirow[t]{6}{*}{ Kiilima } & Degratias farm & $2.84 \mathrm{~h}$ & $441.07 \mathrm{~h}$ & $3.53 \mathrm{~m}$ & $1.09 \mathrm{~m}$ \\
\hline & & Ifunya farm & $3.98 \mathrm{~h}$ & $414.29 \mathrm{~h}$ & $2.24 \mathrm{~m}$ & $1.58 \mathrm{~m}$ \\
\hline & & Baguma farm & $6.95 \mathrm{~h}$ & $241.97 \mathrm{~h}$ & $2.54 \mathrm{~m}$ & $2.34 \mathrm{~h}$ \\
\hline & & Respicius farm & $3.96 \mathrm{~h}$ & $233.93 \mathrm{~h}$ & $2.24 \mathrm{~m}$ & $1.72 \mathrm{~m}$ \\
\hline & & Godwin farm & $5.51 \mathrm{~h}$ & $336.71 \mathrm{~h}$ & $4.22 \mathrm{~m}$ & $3.44 \mathrm{~h}$ \\
\hline & & TARI Maruku Centre & $0.89 \mathrm{~m}$ & $19.50 \mathrm{~h}$ & $9.03 \mathrm{~h}$ & $0.87 \mathrm{~m}$ \\
\hline \multirow[t]{11}{*}{ Missenyi } & \multirow[t]{5}{*}{ Igayaza } & Farmers Extension Centre & $4.89 \mathrm{~h}$ & $437.50 \mathrm{~h}$ & $16.10 \mathrm{~m}$ & $3.28 \mathrm{~h}$ \\
\hline & & Masood farm & $6.99 \mathrm{~h}$ & $446.43 \mathrm{~h}$ & $48.62 \mathrm{~m}$ & $2.66 \mathrm{~h}$ \\
\hline & & Kaloli farm & $7.67 \mathrm{~h}$ & $271.43 \mathrm{~h}$ & $37.07 \mathrm{~m}$ & $1.72 \mathrm{~m}$ \\
\hline & & Rubega farm & $9.80 \mathrm{~h}$ & $337.50 \mathrm{~h}$ & $22.41 \mathrm{~m}$ & $2.19 \mathrm{~h}$ \\
\hline & & Tautus farm & $4.20 \mathrm{~h}$ & $473.21 \mathrm{~h}$ & $18.97 \mathrm{~m}$ & $3.44 \mathrm{~h}$ \\
\hline & \multirow[t]{6}{*}{ Mabuye } & Mhonge farm & $18.41 \mathrm{~h}$ & $467.86 \mathrm{~h}$ & $29.28 \mathrm{~m}$ & $4.22 \mathrm{~h}$ \\
\hline & & Maida farm & $15.32 \mathrm{~h}$ & $426.76 \mathrm{~h}$ & $70.34 \mathrm{~m}$ & $2.50 \mathrm{~h}$ \\
\hline & & Mabuye society & $9.66 \mathrm{~h}$ & $160.71 \mathrm{~h}$ & $52.59 \mathrm{~m}$ & $0.94 \mathrm{~m}$ \\
\hline & & Pascal farm & $6.11 \mathrm{~h}$ & $137.50 \mathrm{~h}$ & $60.34 \mathrm{~m}$ & $1.88 \mathrm{~m}$ \\
\hline & & Gervas farm & $10.89 \mathrm{~h}$ & $105.29 \mathrm{~h}$ & $37.93 \mathrm{~m}$ & $0.78 \mathrm{~m}$ \\
\hline & & Mabuye Primary School & $0.83 \mathrm{~m}$ & $33.73 \mathrm{~h}$ & $1.48 \mathrm{~m}$ & $0.59 \mathrm{~m}$ \\
\hline \multirow[t]{11}{*}{ Biharamulo } & \multirow[t]{5}{*}{ Rukirwengama } & Edmund farm & $2.76 \mathrm{~h}$ & $89.29 \mathrm{~h}$ & $28.45 \mathrm{~m}$ & $1.25 \mathrm{~m}$ \\
\hline & & Benjamin farm & $1.93 \mathrm{~m}$ & $41.07 \mathrm{~h}$ & $29.31 \mathrm{~m}$ & $0.47 \mathrm{~m}$ \\
\hline & & Chubwa farm & $2.22 \mathrm{~h}$ & $94.29 \mathrm{~h}$ & $25.66 \mathrm{~m}$ & $0.47 \mathrm{~m}$ \\
\hline & & Wilson farm & $2.05 \mathrm{~h}$ & $46.43 \mathrm{~h}$ & $21.25 \mathrm{~m}$ & $1.09 \mathrm{~m}$ \\
\hline & & Mtanzania farm & $2.27 \mathrm{~h}$ & $37.50 \mathrm{~h}$ & $37.07 \mathrm{~m}$ & $1.25 \mathrm{~m}$ \\
\hline & \multirow[t]{6}{*}{ Rukaragata } & Yustina farm & $3.24 \mathrm{~h}$ & $44.04 \mathrm{~h}$ & $37.07 \mathrm{~m}$ & $2.50 \mathrm{~h}$ \\
\hline & & Chinga farm & $3.01 \mathrm{~h}$ & $83.93 \mathrm{~h}$ & $41.55 \mathrm{~m}$ & $1.25 \mathrm{~m}$ \\
\hline & & Mkanirwa farm & $3.18 \mathrm{~h}$ & $87.50 \mathrm{~h}$ & $33.62 \mathrm{~m}$ & $2.19 \mathrm{~h}$ \\
\hline & & Village Office & $3.69 \mathrm{~h}$ & $105.79 \mathrm{~h}$ & $33.62 \mathrm{~m}$ & $2.34 \mathrm{~h}$ \\
\hline & & Mutalemwa farm & $3.13 \mathrm{~h}$ & $64.29 \mathrm{~h}$ & $50.00 \mathrm{~m}$ & $2.34 \mathrm{~h}$ \\
\hline & & Farmers Extension Centre & $1.38 \mathrm{~m}$ & $13.86 \mathrm{~h}$ & $26.19 \mathrm{~h}$ & $3.34 \mathrm{~h}$ \\
\hline
\end{tabular}

Micronutrient: $\mathrm{Zn}=$ zinc, $\mathrm{Fe}=$ iron, $\mathrm{Mn}=$ manganese, $\mathrm{Cu}=$ copper.

Rating: $1=$ low, $\mathrm{m}=$ medium, h=high.

Extractable manganese $(\mathrm{Mn})$ of the studied fields was medium, with the values ranging from $2.24-0.03 \mathrm{mg} \mathrm{kg}^{-1}$, $1.48-70.34 \mathrm{mg} \mathrm{kg}^{-1}$ and $21.25-50.00 \mathrm{mg} \mathrm{kg}^{-1}$ in Bukoba, Missenyi and Biharamulo Districts, respectively [67, 62, 63]. This signified favourable levels of extractable $\mathrm{Mn}$ in all studied pedons. Extractable copper $(\mathrm{Cu})$ of the studied fields ranged from medium level of $0.87,0.59$ and $0.47 \mathrm{mg}$ $\mathrm{kg}^{-1}$ in Bukoba, Missenyi and Biharamulo, respectively, to high level of $3.44,4.22$ and $3.34 \mathrm{mg} \mathrm{kg}^{-1}$ in Bukoba, Missenyi and Biharamulo, resppecively [62, 63]. In Bukoba District, about $55 \%$ and $45 \%$ of the studied fields had medium and high exchangeable $\mathrm{Cu}$, respectively, while in Missenyi District, about $46 \%$ and $54 \%$ of the studied fields had medium and high extractable $\mathrm{Cu}$, respectively. In Biharamulo District, about $55 \%$ and $45 \%$ of the studied fields had medium and high extractable $\mathrm{Cu}$, respectively. Proper management of $\mathrm{Cu}$ in those fields with high levels of $\mathrm{Cu}$ is desirable, for example, proper or limited use of $\mathrm{Cu}-$ based fungicides [64].

\subsubsection{Nutrient Balances in the Soils of the Study Area}

The balance of nutrients in the soil is very important as it influences the availability and uptake of nutrients by the plants. The abundance or deficit of one nutrient in the soil may affect the availability of other nutrients by inducing deficiencies of nutrients present in good quantities [68, 60]. In this study, therefore, nutrient balances were determined using the ratios of $\mathrm{Ca}: \mathrm{Mg}$, Ca: TEB, Mg: K and (K: TEB)\%.

The $\mathrm{Ca}: \mathrm{Mg}$ ratios of the studied fields ranged from favourable, with values of 2.42, 1.20 and 2.34 for some soils of Bukoba, Missenyi and Biharamulo Districts, respectively, to unfavourable, with the value of $6.23,5.37$ and 1.14 for some soils of Bukoba, Missenyi and Biharamulo Districts, respectively (Table 8 ). Other researchers $[36,60]$ reported that the ratios between 1.2 and 5.2 are favourable for crop growth and development. In Bukoba District, about $73 \%$ and $27 \%$ of the fields had favourable and unfavourable $\mathrm{Ca}: \mathrm{Mg}$ ratios, respectively while, in Missenyi about $55 \%$ and $45 \%$ of the fields had favourable and unfavourable $\mathrm{Ca}: \mathrm{Mg}$ ratios, respectively. In Biharamulo, about $91 \%$ and $9 \%$ of the fields had favourable and unfavourable $\mathrm{Ca}: \mathrm{Mg}$ ratios, respectively. Notably, However, [69] reported that presence of more calcium than magnesium in the soils signifies good conditions for crop growth, in terms of improved gas exchange, good clay aggregation and soil structure stability. The soils with unfavourable $\mathrm{Ca}: \mathrm{Mg}$ ratios can lead to nutrient imbalance in the soils, which limit the uptake of both 
$\mathrm{Ca}$ and $\mathrm{Mg}$ by plants $[68,60]$.

Table 8. Nutrient balance levels and ratings of the studied soils in Bukoba, Missenyi and Biharamulo Districts, Tanzania.

\begin{tabular}{|c|c|c|c|c|c|c|}
\hline District & Village & Soil sampling site & Ca: $\mathrm{Mg}$ & Ca: TEB & Mg: $\mathrm{K}$ & $\%(\mathrm{~K}: \mathrm{TEB})$ \\
\hline \multirow[t]{11}{*}{ Bukoba } & \multirow{5}{*}{ Butairuka } & Rushabirwa farm & $3.55 \mathrm{f}$ & 0.76 uf & 13.38 uf & $1.60 \mathrm{uf}$ \\
\hline & & Mpanju farm & $3.17 \mathrm{f}$ & 0.73 uf & 11.56 uf & $2.00 \mathrm{uf}$ \\
\hline & & Kahigi farm & $5.28 \mathrm{uf}$ & $0.81 \mathrm{uf}$ & $6.00 \mathrm{uf}$ & $2.55 \mathrm{f}$ \\
\hline & & Bana farm & 5.59 uf & $0.8 \mathrm{uf}$ & $7.50 \mathrm{uf}$ & $1.95 \mathrm{uf}$ \\
\hline & & Kyabitara farm & 6.23 uf & 0.82 uf & $4.08 \mathrm{uf}$ & $3.23 \mathrm{f}$ \\
\hline & \multirow[t]{6}{*}{ Kiilima } & Degratias farm & $3.59 \mathrm{f}$ & $0.73 \mathrm{uf}$ & $3.56 \mathrm{f}$ & $5.68 \mathrm{f}$ \\
\hline & & Ifunya farm & $3.73 \mathrm{f}$ & 0.75 uf & $6.25 \mathrm{uf}$ & $3.20 \mathrm{f}$ \\
\hline & & Baguma farm & $3.19 \mathrm{f}$ & 0.71 uf & 5.14 uf & $4.31 \mathrm{f}$ \\
\hline & & Respicius farm & $2.64 \mathrm{f}$ & 0.69 uf & 9.64 uf & $2.71 \mathrm{f}$ \\
\hline & & Godwin farm & $2.42 \mathrm{f}$ & $0.68 \mathrm{uf}$ & 10.56 uf & $2.66 \mathrm{f}$ \\
\hline & & TARI Maruku Centre & $4.45 \mathrm{f}$ & 0.74 uf & $2.93 \mathrm{f}$ & $5.68 \mathrm{f}$ \\
\hline \multirow[t]{11}{*}{ Missenyi } & \multirow[t]{5}{*}{ Igayaza } & Farmers Extension Centre & 0.98 uf & $0.46 \mathrm{f}$ & 9.75 uf & $4.84 \mathrm{f}$ \\
\hline & & Masood farm & $1.20 \mathrm{f}$ & 0.52 uf & 9.12 uf & $4.60 \mathrm{f}$ \\
\hline & & Kaloli farm & 0.53 uf & $0.31 \mathrm{f}$ & 7.25 uf & $8.17 \mathrm{f}$ \\
\hline & & Rubega farm & 0.89 uf & $0.44 \mathrm{f}$ & 8.69 uf & $5.63 \mathrm{f}$ \\
\hline & & Tautus farm & 0.86 uf & $0.43 \mathrm{f}$ & $8.97 \mathrm{uf}$ & $5.60 \mathrm{f}$ \\
\hline & \multirow[t]{6}{*}{ Mabuye } & Mhonge farm & $2.84 \mathrm{f}$ & 0.67 uf & $2.81 \mathrm{f}$ & $8.42 \mathrm{f}$ \\
\hline & & Maida farm & $2.51 \mathrm{f}$ & 0.68 uf & $6.62 \mathrm{uf}$ & $4.08 \mathrm{f}$ \\
\hline & & Mabuye society & $2.79 \mathrm{f}$ & 0.70 uf & $6.11 \mathrm{uf}$ & $4.11 \mathrm{f}$ \\
\hline & & Pascal farm & $5.37 \mathrm{uf}$ & 0.79 uf & $3.00 \mathrm{f}$ & $4.90 \mathrm{f}$ \\
\hline & & Gervas farm & $4.56 \mathrm{f}$ & 0.78 uf & $3.64 \mathrm{f}$ & $4.69 \mathrm{f}$ \\
\hline & & Mabuye Primary School & $4.14 \mathrm{f}$ & 0.70 uf & $2.75 \mathrm{f}$ & $6.15 \mathrm{f}$ \\
\hline \multirow[t]{11}{*}{ Biharamulo } & \multirow[t]{5}{*}{ Rukirwengama } & Edmund farm & $1.74 \mathrm{f}$ & $0.61 \mathrm{uf}$ & 17.25 uf & $2.00 \mathrm{uf}$ \\
\hline & & Benjamin farm & $2.11 \mathrm{f}$ & 0.65 uf & $13.30 \mathrm{uf}$ & $2.31 \mathrm{f}$ \\
\hline & & Chubwa farm & $2.34 \mathrm{f}$ & 0.68 uf & 15.67 uf & $1.85 \mathrm{uf}$ \\
\hline & & Wilson farm & $2.21 \mathrm{f}$ & 0.67 uf & $14.90 \mathrm{uf}$ & $2.00 \mathrm{uf}$ \\
\hline & & Mtanzania farm & 1.14 uf & 0.52 uf & 24.60 uf & 1.85 uf \\
\hline & \multirow[t]{6}{*}{ Rukaragata } & Yustina farm & $2.10 \mathrm{f}$ & 0.64 uf & $3.57 \mathrm{f}$ & $3.69 \mathrm{f}$ \\
\hline & & Chinga farm & $1.58 \mathrm{f}$ & 0.60 uf & $19.90 \mathrm{uf}$ & $1.90 \mathrm{uf}$ \\
\hline & & Mkanirwa farm & $2.17 \mathrm{f}$ & 0.66 uf & 9.48 uf & $3.20 \mathrm{f}$ \\
\hline & & Village Office & $1.73 \mathrm{f}$ & $0.61 \mathrm{uf}$ & 15.05 uf & $2.36 \mathrm{f}$ \\
\hline & & Mutalemwa farm & $1.98 \mathrm{f}$ & 0.65 uf & $17.20 \mathrm{uf}$ & $1.91 \mathrm{uf}$ \\
\hline & & Farmers Extension Centre & $3.03 \mathrm{f}$ & 0.73 uf & 9.81 uf & $2.44 \mathrm{f}$ \\
\hline
\end{tabular}

Chemical property: $\mathrm{Ca}=$ calcium, $\mathrm{Mg}=$ magnessium, $\mathrm{K}=$ potassium, $\mathrm{TEB}=$ total exchaengable bases.

Rating: $\mathrm{f}=$ favourable, uf=unfavourable.

The Ca: TEB ratios of the studied fields was unfavourable, with values ranging from $0.68-0.82$ and from $0.52-0.73$ in Bukoba and Biharamulo Districts, respectively. In Missenyi District, it ranged from favourable (0.31) to unfavourable (0.78). The Ca: TEB values above 0.5 are unfavourable and affect the uptake of other exchangeable bases, particularly $\mathrm{K}$ and $\mathrm{Mg}$ [36]. In Bukoba and Biharamulo Districts, all studied fields had unfavourable Ca: TEB ratios while in Missenyi District, about $36 \%$ and $64 \%$ of the studied fields had favourable and unfavourable Ca: TEB ratio, respectively.

The $\mathrm{Mg}$ : $\mathrm{K}$ ratios of the studied fields ranged from favourable, with values ranging from 2.93 - 3.56, 2.75 - 3.64 to unfavourable with values ranging from $4.1-13.38,6.11$ 9.75 in Bukoba and Missenyi Districts, respectively. In Biharamulo Districts, it ranged from favourable (3.57) to unfavourable with values ranging from 9.48 - 24.60 (Table 8). The Mg: $\mathrm{K}$ ratios ranging from 1 - 4 are favourable for crop growth and development [36, 44]. In Bukoba District, about $18 \%$ and $82 \%$ of the studied fields had favourable and unfavourable $\mathrm{Mg}$ : $\mathrm{K}$ ratios, respectively, while in Missenyi District, about $36 \%$ and $64 \%$ of the studied fields had favourable and unfavourable $\mathrm{Mg}$ : $\mathrm{K}$ ratios, respectively. In Biharamulo, about $9 \%$ and $91 \%$ of the studied fields had favourable and unfavourable $\mathrm{Mg}$ : $\mathrm{K}$ ratios, respectively. This study revealed that about $83.3 \%$ of the studied fields in the study area had unfavourable $\mathrm{Mg}$ : $\mathrm{K}$ ratios caused by low amount of $\mathrm{K}$ in the soils. Therefore, use of $\mathrm{K}$-containing fertilizers such as muriate of potash (MOP), sulphate of potash, Potassium nitrate, or potassium meta-phosphate in those fields is desirable for sustainable crop production and optimum yields.

\subsubsection{Summary of Some Soil Chemical Properties of the Studied Fields in Bukoba, Missenyi and Biharamulo Districts, Tanzania}

The mean values and ranges of some soil chemical properties in the studied fields in Bukoba, Missenyi and Biharamulo Districts are presented in Table 9. The soil $\mathrm{pH}$ of the studied fields ranged from 5.1 - 5.7, $5.2-6.1$ and 5.1 - 6.5, with the mean value of $5.23 \pm 0.21,5.61 \pm 0.26$ and $5.63 \pm 0.43$ (Table 9), which are strongly acid, medium acid and medium acid in Bukoba, Missenyi and Biharamulo Districts, respectively $[36,44]$. The $\mathrm{EC}$ of the studied fields ranged from $0.03-0.08,0.03-0.17$ and $0.03-0.04 \mathrm{dS} \mathrm{m}^{-1}$, with the mean values of $0.05 \pm 0.02,0.07 \pm 0.04$ and $0.04 \pm 0.01 \mathrm{dS} \mathrm{m}^{-1}$, which are all low in all districts [43, 44]. 
The OC of the studied fields ranged from $2.54-5.61 \%$, $1.26-2.73 \%$ and $0.65-1.76 \%$, with the mean values of $3.50 \pm 0.91,1.94 \pm 0.43$ and $1.15 \pm 0.40$ which are high, medium and low OC in Bukoba, Missenyi and Biharamulo Districts, respectively $[43,44]$. The TN of the studied fields ranged from
$0.23-0.41 \%, 0.11-0.19 \%$ and $0.04-0.08 \%$, with the mean values of $0.28 \pm 0.05,0.15 \pm 0.03$ and $0.06 \pm 0.02$, which are medium, low and very low $\mathrm{TN}$ in Bukoba, Missenyi and Biharamulo Districts, respectively [36, 43, 44]. The mean values of other chemical properties are as presented in Table 9.

Table 9. Mean values, ratings and ranges of some soil chemical properties of the studied fields in Bukoba, Missenyi and Biharamulo Districts, Tanzania.

\begin{tabular}{|c|c|c|c|c|c|c|}
\hline \multirow{2}{*}{ Soil chemical property } & \multicolumn{2}{|l|}{ Bukoba District } & \multicolumn{2}{|l|}{ Missenyi District } & \multicolumn{2}{|c|}{ Biharamulo District } \\
\hline & Range & Mean & Range & Mean & Range & Mean \\
\hline $\mathrm{pH}$ & $5.1-5.7$ & $5.23 \pm 0.21 \mathrm{sta}$ & $5.2-6.1$ & $5.61 \pm 0.26 \mathrm{ma}$ & $5.1-6.5$ & $5.63 \pm 0.43 \mathrm{ma}$ \\
\hline $\mathrm{EC}\left(\mathrm{dS} \mathrm{m} \mathrm{m}^{-1}\right)$ & $0.03-0.08$ & $0.05 \pm 0.021$ & $0.03-0.17$ & $0.07 \pm 0.041$ & $0.03-0.04$ & $0.04 \pm 0.011$ \\
\hline $\mathrm{OC}(\%)$ & $2.54-5.61$ & $3.50 \pm 0.91 \mathrm{~h}$ & $1.26-2.73$ & $1.94 \pm 0.43 \mathrm{~m}$ & $0.65-1.76$ & $1.15 \pm 0.401$ \\
\hline $\mathrm{TN}(\%)$ & $0.23-0.41$ & $0.28 \pm 0.05 \mathrm{~m}$ & $0.11-0.19$ & $0.15 \pm 0.031$ & $0.04-0.08$ & $0.06 \pm 0.02 \mathrm{vl}$ \\
\hline $\mathrm{CN}$ ratio & $10-14$ & $12.40 \pm 1.43 \mathrm{gq}$ & $9-17$ & $13.10 \pm 3.25 \mathrm{gq}$ & $14-22$ & $18.20 \pm 3.1 \mathrm{mq}$ \\
\hline $\mathrm{P}\left(\mathrm{mg} \mathrm{kg}^{-1}\right)$ & $2.55-19.67$ & $7.85 \pm 5.37 \mathrm{~m}$ & $21.91-86.44$ & $42.45 \pm 21.93 \mathrm{~h}$ & $0.44-6.04$ & $2.35 \pm 1.761$ \\
\hline $\mathrm{Ca}\left(\operatorname{cmol}(+) \mathrm{kg}^{-1}\right)$ & $2.30-3.80$ & $3.05 \pm 0.63 \mathrm{~m}$ & $2.30-10.80$ & $5.50 \pm 3.39 \mathrm{~m}$ & $2.80-7.30$ & $4.94 \pm 1.79 \mathrm{~m}$ \\
\hline $\operatorname{Mg}\left(\operatorname{cmol}(+) \mathrm{kg}^{-1}\right)$ & $0.07-0.53$ & $0.82 \pm .20 \mathrm{~m}$ & $2.01-4.35$ & $2.71 \pm 0.70 \mathrm{~h}$ & $1.33-3.98$ & $2.66 \pm 0.96 \mathrm{~h}$ \\
\hline $\mathrm{K}\left(\operatorname{cmol}(+) \mathrm{kg}^{-1}\right)$ & $0.08-0.18$ & $0.12 \pm 0.031 \mathrm{vl}$ & $0.24-0.98$ & $0.48 \pm 0.23 \mathrm{~m}$ & $0.09-0.42$ & $0.19 \pm 0.111$ \\
\hline $\mathrm{Na}\left(\mathrm{cmol}(+) \mathrm{kg}^{-1}\right)$ & $0.04-0.09$ & $0.07 \pm 0.02 \mathrm{vl}$ & $0.05-0.18$ & $0.10 \pm 0.041$ & $0.04-0.14$ & $0.07 \pm 0.03 \mathrm{vl}$ \\
\hline $\mathrm{CEC}\left(\operatorname{cmol}(+) \mathrm{kg}^{-1}\right)$ & $5.80-16.80$ & $10.13 \pm 3.91$ & $13.20-23.00$ & $16.89 \pm 3.00 \mathrm{~m}$ & $5.20-15.00$ & $10.26 \pm 3.901$ \\
\hline $\operatorname{ESP}(\%)$ & $0.36-1.05$ & $0.71 \pm 0.25 \mathrm{nsd}$ & $0.31-0.91$ & $0.58 \pm 0.16 \mathrm{nsd}$ & $0.27-1.92$ & $0.79 \pm 0.58 \mathrm{nsd}$ \\
\hline BS $(\%)$ & $19.35-86.21$ & $47.62 \pm 23.54 \mathrm{~m}$ & $32.32-78.10$ & $51.68 \pm 16.65 \mathrm{~m}$ & $67.63-98.25$ & $77.75 \pm 9.7 \mathrm{~h}$ \\
\hline $\mathrm{Fe}\left(\mathrm{mg} \mathrm{kg}^{-1}\right)$ & $233.93-444.64$ & $353.03 \pm 74.17 \mathrm{~h}$ & $105.29-446.43$ & $326.42 \pm 146.65 \mathrm{~h}$ & $37.50-105.76$ & $69.41 \pm 25.59 \mathrm{~h}$ \\
\hline $\operatorname{Mn}\left(\mathrm{mg} \mathrm{kg}^{-1}\right)$ & $2.24-4.22$ & $3.12 \pm 0.73826 \mathrm{~m}$ & $16.10-70.34$ & $39.37 \pm 18.30 \mathrm{~h}$ & $21.25-50.00$ & $33.76 \pm 8.28 \mathrm{~h}$ \\
\hline $\mathrm{Cu}\left(\mathrm{mg} \mathrm{kg}^{-1}\right)$ & $1.09-3.44$ & $2.13 \pm 0.50 \mathrm{~h}$ & $0.78-4.22$ & $2.46 \pm 0.75 \mathrm{~h}$ & $0.47-2.50$ & $1.70 \pm 0.66 \mathrm{~m}$ \\
\hline
\end{tabular}

Chemical property: $\mathrm{EC}=$ electrical conductivity; $\mathrm{SOM}=$ soil organic matter; $\mathrm{TN}=$ total nitrogen; $\mathrm{CN}=$ carbon: nitrogen ratio; $\mathrm{P}=$ phosphorus; $\mathrm{SO}$ - $\mathrm{S}=$ sulphatesulphur; $\mathrm{Ca}=$ calcium; $\mathrm{Mg}=$ magnesium; $\mathrm{K}=$ potassium; $\mathrm{Na}=$ sodium; $\mathrm{CEC}=$ cation exchange capacity; $\mathrm{ESP}=$ exchangeable sodium percentage; $\mathrm{BS}=$ base saturation; $\mathrm{Zn}=$ zinc; $\mathrm{Fe}=$ iron; $\mathrm{Mn}=$ manganese; $\mathrm{Cu}=$ copper.

Rating: sta=strong acidic; ma=moderate acidic; $\mathrm{l}=\mathrm{low}$; $\mathrm{l}=$ =very low; $\mathrm{h}=$ high; $\mathrm{m}=$ medium; gq=good quality; mq=moderate quality; nsd=non-sodic.

\subsubsection{Correlation Among Some Soil Chemical Properties}

\section{i. Correlation in Bukoba District}

Pearson's correlations among some chemical properties of the soils of the studied fields in Bukoba District are presented in Table 10. The results revealed that the $\mathrm{pH}$ of the soils correlated positively $(\mathrm{r}=0.74)$ and significantly $(p \leq 0.05)$ with available $\mathrm{P}$, which signified that the soil $\mathrm{pH}$ had an influence on the available $\mathrm{P}$ since as $\mathrm{pH}$ increases, the available $\mathrm{P}$ also increases, and the vice-versa. Soils with low $\mathrm{pH}$ tend to inhibit the availability of $\mathrm{P}$ in the soil solution due to fixation of $\mathrm{P}[70,17]$ high $\mathrm{Fe}$ and $\mathrm{Al}$ in the soil solution. Increase in $\mathrm{pH}$ result in the precipitation of exchangeable and soluble $\mathrm{Al}$ and $\mathrm{Fe}$ as insoluble $\mathrm{Al}$ and $\mathrm{Fe}$ hydroxides, thus reducing the concentrations of $\mathrm{Al}$ and $\mathrm{Fe}$ in the soil solution [70], which increase $\mathrm{P}$ in the soil solution for plant uptake. Other researchers [71, 53] reported similar results. The OC of the soils correlated positively at $\mathrm{r}=0.74, \mathrm{r}=0.75, \mathrm{r}=0.71$ and $\mathrm{r}=0.67$ and significantly $(p \leq 0.05)$ with $\mathrm{C}: \mathrm{N}$ ratio, $\mathrm{Na}, \mathrm{CEC}$ and $\mathrm{Zn}$, respectively and it correlated positively $(\mathrm{r}=92)$ and highly significantly $(p \leq 0.01)$ with $\mathrm{TN}$. This signified that OC had an influence on the $\mathrm{C}: \mathrm{N}$ ratio, Na, CEC Zn and TN. This means that as $\mathrm{OC}$ increases, the $\mathrm{C}: \mathrm{N}$ ratio, $\mathrm{Na}, \mathrm{CEC}, \mathrm{Zn}$ and $\mathrm{TN}$ also increase and vice-versa. The $\mathrm{OC}$ is a major component of soil organic matter. Soils with high OC content reflect high organic matter [17]. The increase of OM in the soil creates a soil nutrient pool for plant nutrients as the decomposition of OM releases some soil nutrients like $\mathrm{N}, \mathrm{K}$, $\mathrm{Ca}, \mathrm{Mg}$ and micronutrients such as $\mathrm{Zn} \mathrm{[3,} \mathrm{72].} \mathrm{Other}$ researchers [73, 74, 53] reported similar results of positive and significant correlation between $\mathrm{OC}$ and $\mathrm{TN}$.

Available $\mathrm{P}$ of the soils of the studied fields correlated positively $(\mathrm{r}=0.82)$ and negatively $(\mathrm{r}=-0.84)$ and highly significantly $(p \leq 0.01)$ with $\mathrm{Mn}$ and $\mathrm{Na}$, respectively. The results also showed that the CEC of the soils correlated negatively at $\mathrm{r}=-0.72$ and $\mathrm{r}=-0.94$ and significantly $(p \leq 0.05)$ and highly significantly $(p \leq 0.01)$ with ESP and BS, respectively. This signified that $\mathrm{CEC}$ had a negative effect on ESP and BS since as CEC increases, ESP and BS decrease, and vice-versa. This is because, the $\mathrm{BS}$ is calculated by dividing the TEB by CEC [36], which means that the higher the $\mathrm{CEC}$ than the TEB, the lower the BS, and vice-versa.

Table 10. Correlations among some chemical properties of the soils of studied fields in Bukoba District, Tanzania.

\begin{tabular}{|c|c|c|c|c|c|c|c|c|c|c|c|c|c|c|c|c|c|c|}
\hline $\begin{array}{l}\text { Chemical } \\
\text { Property }\end{array}$ & 1 & 2 & 3 & 4 & 5 & 6 & 7 & 8 & 9 & 10 & 11 & 12 & 13 & 14 & 15 & 16 & 17 & 18 \\
\hline 1. $\mathrm{pH}$ & - & & & & & & & & & & & & & & & & & \\
\hline 2. EC & 0.25 & - & & & & & & & & & & & & & & & & \\
\hline 3. $\mathrm{OC}$ & -0.29 & -0.09 & - & & & & & & & & & & & & & & & \\
\hline 4. $\mathrm{TN}$ & -0.21 & -0.10 & $0.92^{* *}$ & - & & & & & & & & & & & & & & \\
\hline
\end{tabular}




\begin{tabular}{|c|c|c|c|c|c|c|c|c|c|c|c|c|c|c|c|c|c|c|}
\hline $\begin{array}{l}\text { Chemical } \\
\text { Property }\end{array}$ & 1 & 2 & 3 & 4 & 5 & 6 & 7 & 8 & 9 & 10 & 11 & 12 & 13 & 14 & 15 & 16 & 17 & 18 \\
\hline 5. $\mathrm{C}: \mathrm{N}$ ratio & -0.35 & 0.04 & $0.74^{*}$ & 0.42 & - & & & & & & & & & & & & & \\
\hline 6. P & $0.74^{*}$ & 0.12 & -0.63 & -0.37 & $-0.81^{* *}$ & - & & & & & & & & & & & & \\
\hline 7. $\mathrm{SO}_{4}-\mathrm{S}$ & 0.58 & -0.01 & -0.50 & -0.60 & -0.18 & 0.40 & - & & & & & & & & & & & \\
\hline 8. $\mathrm{Ca}$ & -0.07 & -0.22 & -0.50 & $-0.73^{*}$ & 0.06 & -0.16 & 0.43 & - & & & & & & & & & & \\
\hline 9. $\mathrm{Mg}$ & -0.15 & -0.52 & -0.19 & -0.13 & -0.31 & 0.03 & -0.01 & 0.05 & - & & & & & & & & & \\
\hline 10. K & -0.31 & 0.52 & 0.33 & 0.44 & 0.10 & -0.15 & -0.54 & -0.54 & $-0.65^{*}$ & - & & & & & & & & \\
\hline 12. $\mathrm{CEC}$ & -0.26 & -0.02 & $0.71^{*}$ & $0.82^{* *}$ & 0.25 & -0.23 & -0.57 & $-0.85^{* *}$ & -0.15 & 0.57 & 0.45 & - & & & & & & \\
\hline 13. ESP & -0.19 & -0.13 & -0.15 & -0.40 & 0.31 & -0.42 & 0.40 & $0.77^{* *}$ & 0.16 & -0.44 & 0.28 & $-0.72^{*}$ & - & & & & & \\
\hline 14. BS & 0.06 & -0.19 & -0.57 & $-0.73^{*}$ & -0.09 & 0.03 & 0.40 & $0.94^{* *}$ & 0.18 & -0.61 & -0.36 & $-0.94^{* *}$ & $0.74^{*}$ & - & & & & \\
\hline 15. $\mathrm{Zn}$ & 0.07 & -0.12 & $0.67^{*}$ & $0.84^{* *}$ & 0.11 & -0.03 & -0.53 & $-0.83^{* *}$ & 0.10 & 0.23 & 0.28 & $0.84^{* *}$ & $-0.70^{*}$ & $-0.79^{* *}$ & - & & & \\
\hline 16. $\mathrm{Fe}$ & 0.10 & 0.18 & -0.56 & -0.58 & -0.23 & 0.39 & 0.46 & 0.24 & -0.35 & 0.08 & -0.50 & -0.25 & -0.06 & 0.21 & -0.56 & - & & \\
\hline 17. Mn & 0.58 & -0.01 & -0.53 & -0.38 & -0.55 & $0.82^{* *}$ & 0.42 & 0.04 & 0.14 & -0.34 & $-0.74^{*}$ & -0.41 & -0.10 & 0.30 & -0.19 & 0.46 & - & \\
\hline 18. $\mathrm{Cu}$ & 0.43 & -.19 & -0.00 & -0.07 & 0.07 & 0.06 & 0.52 & 0.39 & 0.12 & -0.57 & -0.02 & -0.53 & 0.59 & 0.50 & -0.20 & -0.23 & 0.29 & - \\
\hline
\end{tabular}

Pearson's correlation at $95 \%$ confidence level, * significant at $\mathrm{P} \leq 0.05$, ** significant at $\mathrm{P} \leq 0.01$; where $\mathrm{P}$ is the probability.

Chemical property: $\mathrm{EC}=$ electrical conductivity, $\mathrm{OC}=$ organic carbon, $\mathrm{TN}=$ total nitrogen, $\mathrm{C}: \mathrm{N}=$ carbon: nitrogen ratio, $\mathrm{P}=\mathrm{phosphorus,} \mathrm{SO} \mathrm{H}_{4} \mathrm{~S}=$ sulphate- sulphur, $\mathrm{Ca}=$ calcium, $\mathrm{Mg}=$ magnessium, $\mathrm{K}=$ potassium, $\mathrm{Na}=$ sodium, $\mathrm{CEC}=$ cation exchange capacity, $\mathrm{ESP}=$ exchangeable sodium percent, $\mathrm{BS}=$ base saturation, $\mathrm{Zn}=\mathrm{zinc}$, $\mathrm{Fe}=$ iron, $\mathrm{Mn}=$ manganese, $\mathrm{Cu}=$ copper.

\section{ii. Correlation in Missenyi District}

Pearson's correlations among some chemical properties of the soils of the studied fields in Missenyi District are presented in Table 11. The results revealed that $\mathrm{pH}$ of the soils correlated negatively at $\mathrm{r}=0.67, \mathrm{r}=073$ and $\mathrm{r}=0.72$ and significantly $(p \leq 0.05)$ with $\mathrm{C}: \mathrm{N}$ ratio, $\mathrm{Fe}$ and $\mathrm{Cu}$, respectively. This signified that the soil $\mathrm{pH}$ had a negative effect on $\mathrm{C}: \mathrm{N}$ ratio, $\mathrm{Fe}$ and $\mathrm{Cu}$ since as $\mathrm{pH}$ increases, the $\mathrm{C}: \mathrm{N}$ ratio, $\mathrm{Fe}$ and $\mathrm{Cu}$ decrease, and vice-versa. Extractable $\mathrm{Cu}$ and $\mathrm{Fe}$ are readily available in acid soil up to toxic level when soil $\mathrm{pH}$ is $<4$ and decreases when the soil $\mathrm{pH}$ increases [36]. The increase in $\mathrm{pH}$, lead to precipitation of extractable $\mathrm{Fe}$ as insoluble Fe hydroxides, thus reducing the concentrations of
Fe in the soil solution [70]. However, [74] reported positive and significant correlations between soil $\mathrm{pH}$ and $\mathrm{Fe}$ due to high content of $\mathrm{OM}$ in the soil. They concluded that soil $\mathrm{pH}$ correlates positively with $\mathrm{Fe}$ content in the form of power function and not in linear relationship because Fe content in the soil is also influenced by the soil conditions such as, soil compaction, poor soil aeration, presence of other nutrients, leaching and soil erosion. The results also revealed that the $\mathrm{pH}$ correlated positively at $\mathrm{r}=0.70$ and $\mathrm{r}=0.74$ and significantly $(p \leq 0.05)$ with $\mathrm{Ca}$ and $\mathrm{BS}$, respectively, which signified that as soil $\mathrm{pH}$ increases, $\mathrm{Ca}$ and $\mathrm{BS}$ also increase. Other researchers $[36,17,53]$ reported similar results of increased $\mathrm{Ca}$ in the soil when soil $\mathrm{pH}$ increased.

Table 11. Correlations among some chemical properties of the soils of studied fields in Missenyi District, Tanzania.

\begin{tabular}{|c|c|c|c|c|c|c|c|c|c|c|c|c|c|c|c|c|c|c|}
\hline $\begin{array}{l}\text { Chemical } \\
\text { Property }\end{array}$ & 1 & 2 & 3 & 4 & 5 & 6 & 7 & 8 & 9 & 10 & 11 & 12 & 13 & 14 & 15 & 16 & 17 & 18 \\
\hline 1. $\mathrm{pH}$ & - & & & & & & & & & & & & & & & & & \\
\hline 2. $\mathrm{EC}$ & 0.27 & - & & & & & & & & & & & & & & & & \\
\hline 3. $\mathrm{OC}$ & -0.39 & 0.13 & - & & & & & & & & & & & & & & & \\
\hline 4. $\mathrm{TN}$ & 0.27 & 0.32 & 0.31 & - & & & & & & & & & & & & & & \\
\hline 5. $\mathrm{C}: \mathrm{N}$ ratio & $-0.67^{*}$ & -0.20 & $0.69^{*}$ & -0.46 & - & & & & & & & & & & & & & \\
\hline 6. P & 0.21 & -0.31 & 0.14 & -0.07 & 0.13 & - & & & & & & & & & & & & \\
\hline 8. $\mathrm{Ca}$ & $0.70^{*}$ & 0.28 & $-0.65^{*}$ & 0.24 & $-9.79^{* *}$ & -0.37 & $-0.79^{* *}$ & - & & & & & & & & & & \\
\hline 9. $\mathrm{Mg}$ & -0.05 & 0.43 & $0.73^{*}$ & 0.37 & 0.31 & 0.01 & 0.29 & -0.45 & - & & & & & & & & & \\
\hline 10. K & 0.47 & $0.90^{* *}$ & -0.15 & 0.32 & -0.43 & -0.45 & -0.46 & 0.63 & 0.14 & - & & & & & & & & \\
\hline 11. $\mathrm{Na}$ & 0.14 & 0.19 & 0.26 & $0.78^{* *}$ & -0.28 & -0.26 & -0.20 & 0.39 & -0.03 & 0.33 & - & & & & & & & \\
\hline 12. CEC & 0.30 & $0.77^{* *}$ & 0.09 & 0.52 & -0.33 & -0.43 & -0.31 & 0.48 & 0.15 & $0.84^{* *}$ & 0.63 & - & & & & & & \\
\hline 13. ESP & -0.05 & -0.17 & 0.32 & $0.71^{*}$ & -0.13 & -0.07 & -0.02 & 0.17 & -0.10 & -0.07 & $0.90^{* *}$ & 0.23 & - & & & & & \\
\hline 14. BS & $0.74^{*}$ & 0.11 & $-0.72^{*}$ & 0.13 & $-0.79^{* *}$ & -0.26 & $-0.80^{* *}$ & $.90^{* *}$ & -0.35 & 0.43 & 0.11 & 0.13 & -0.01 & - & & & & \\
\hline 17. $\mathrm{Mn}$ & 0.30 & -0.03 & -0.25 & 0.48 & -0.57 & -0.55 & -0.48 & 0.60 & -0.12 & .16 & 0.51 & 0.23 & 0.47 & 0.60 & 0.28 & -0.36 & - & \\
\hline 18. $\mathrm{Cu}$ & $-0.72^{*}$ & 0.15 & 0.29 & -0.15 & 0.48 & -0.09 & 0.35 & -0.42 & 0.03 & -0.02 & -0.02 & 0.14 & -0.03 & $-0.64^{*}$ & 0.05 & $0.91^{* *}$ & -0.51 & - \\
\hline
\end{tabular}

Pearson's correlation at $95 \%$ confidence level, * significant at $\mathrm{P} \leq 0.05$, ** significant at $\mathrm{P} \leq 0.01$; where $\mathrm{P}$ is the probability.

Chemical property: $\mathrm{EC}=$ electrical conductivity, $\mathrm{OC}=$ organic carbon, $\mathrm{TN}=$ total nitrogen, $\mathrm{C}: \mathrm{N}=$ carbon: nitrogen ratio, $\mathrm{P}=\mathrm{phosphorus,} \mathrm{SO} \mathrm{S}_{4} \mathrm{~S}=$ sulphate- sulphur, $\mathrm{Ca}=$ calcium, $\mathrm{Mg}=$ magnessium, $\mathrm{K}=$ potassium, $\mathrm{Na}=$ sodium, $\mathrm{CEC}=$ cation exchange capacity, $\mathrm{ESP}=$ exchangeable sodium percent, $\mathrm{BS}=$ base saturation, $\mathrm{Zn}=\mathrm{Zinc}$, $\mathrm{Fe}=$ iron, $\mathrm{Mn}=$ manganese, $\mathrm{Cu}=$ copper.

The OC of the soils correlated positively at $\mathrm{r}=0.69, \mathrm{r}=0.72$ and $\mathrm{r}=0.73$ and significantly $(p \leq 0.05)$ with $\mathrm{C}: \mathrm{N}$ ratio, $\mathrm{SO}_{4}-\mathrm{S}$ and $\mathrm{Mg}$, respectively. This signified that $\mathrm{OC}$ had an influence on the $\mathrm{C}: \mathrm{N}$ ratio, $\mathrm{SO} 4-\mathrm{S}$ and $\mathrm{Mg}$, which means that as $\mathrm{OC}$ increases, the $\mathrm{C}: \mathrm{N}$ ratio, $\mathrm{SO} 4-\mathrm{S}$ and $\mathrm{Mg}$ also increase and vice-versa. The $\mathrm{OC}$ is a reflection of soil organic matter; 
increase of $\mathrm{OM}$ in the soil creates a soil nutrient pool for plant nutrients since the decomposition of OM releases some soil nutrients [3].

The BS of the soils of the studied fields correlated negatively at $\mathrm{r}=-0.75$ and $\mathrm{r}=-0.65$ and highly significantly $(p \leq 0.01)$ with extractable $\mathrm{Fe}$ and $\mathrm{Cu}$ respectively. This signified that the BS had negative effects on the availability of extractable $\mathrm{Fe}$ and $\mathrm{Cu}$ in the soil since the increase of $\mathrm{BS}$, caused the decrease of $\mathrm{Fe}$ and $\mathrm{Cu}$, and vice-versa. The BS is a measure of exchangeable bases in the soils and high BS reflects the basic cations in the soil $[36,17]$, which are readily available when soil $\mathrm{pH}$ is high (alkaline) as opposed to $\mathrm{Fe}$ and $\mathrm{Cu}$ which are readily available when the soil $\mathrm{pH}$ is low (acid). This substantiates the negative and significant correlation between $\mathrm{BS}$ and micronutrients ( $\mathrm{Fe}$ and $\mathrm{Cu}$ ) observed in the soils of the studied fields in Missenyi District.

iii. Correlation in Biharamulo District

Pearson's correlations among some chemical properties of the soils of the studied fields in Biharamulo District are presented in Table 12. The results revealed that the $\mathrm{pH}$ of the soils correlated positively $(\mathrm{r}=0.64)$ and significantly $(p \leq 0.05)$ with $\mathrm{EC}$, which signified that the soil $\mathrm{pH}$ had an influence on $\mathrm{EC}$, since as $\mathrm{pH}$ increases, the $\mathrm{EC}$ also increases, and viceversa. Soil electrical conductivity relates directly to salinity, which refers the presence of soluble salts in the soils. Soil $\mathrm{pH}$ is not directly affects soil EC but might affects solubility of salts and soil moisture content, as more alkaline soils, have less amount amounts of soluble salts, hence; they reported negative correlation between soil $\mathrm{pH}$ and soil EC [74]. The results of this study therefore, were not similar to that reported by [74]. This was attributed to the very low EC, exchangeable $\mathrm{Na}$ and ESP observed in the soils of the studied fields (Tables 5 and 6).

The OC of the soils correlated positively $(\mathrm{r}=0.70)$ and significantly $(p \leq 0.05)$ with $\mathrm{C}: \mathrm{N}$ ratio. The $\mathrm{OC}$ also correlated positively at $\mathrm{r}=0.85, \mathrm{r}=0.85 \mathrm{r}=0.93 \mathrm{r}=0.97 \mathrm{r}=0.79 \mathrm{r}=0.88$ and $\mathrm{r}=0.89$ and highly significantly $(p \leq 0.01)$ with $\mathrm{TN}, \mathrm{Ca}, \mathrm{Mg}, \mathrm{K}$, $\mathrm{CEC}, \mathrm{Zn}, \mathrm{Mn}$ and $\mathrm{Cu}$, respectively. This signified that $\mathrm{OC}$ had a positive effect on the $\mathrm{C}: \mathrm{N}$ ratio, $\mathrm{TN}, \mathrm{Ca}, \mathrm{Mg}, \mathrm{K}, \mathrm{CEC}, \mathrm{Zn}$, $\mathrm{Mn}$ and $\mathrm{Cu}$. Therefore, as $\mathrm{OC}$ increases, $\mathrm{C}: \mathrm{N}$ ratio, $\mathrm{TN}, \mathrm{Ca}$, $\mathrm{Mg}, \mathrm{K}, \mathrm{CEC}, \mathrm{Zn}, \mathrm{Mn}$ and $\mathrm{Cu}$ also increase, and vice-versa. The OC is a reflection of soil organic matter given that the soil with high OC content reflects high organic matter in the soil [17]. The increase of OM in the soil creates a soil nutrient pool for plant nutrients as the decomposition of OM releases some soil nutrients like $\mathrm{N}, \mathrm{S}, \mathrm{Mg}$ and micronutrients [3, 72, 17]. Exchangeable $\mathrm{Ca}$ of the soils of the studied fields correlated positively at $\mathrm{r}=0.88, \mathrm{r}=0.88 \mathrm{r}=0.98 \mathrm{r}=0.84$ and $\mathrm{r}=0.92$ and highly significantly $(p \leq 0.01)$ with $\mathrm{Mg}, \mathrm{K}, \mathrm{CEC}, \mathrm{Zn}$ and $\mathrm{Cu}$, respectively. This signified that exchangeable $\mathrm{Ca}$ had a positive effect on $\mathrm{Mg}, \mathrm{K}, \mathrm{CEC}, \mathrm{Zn}$ and $\mathrm{Cu}$, in the soils since as $\mathrm{Ca}$ increases, $\mathrm{Mg}, \mathrm{K}, \mathrm{CEC}, \mathrm{Zn}$ and $\mathrm{Cu}$, also increase, and viceversa. Similar results were reported by [53] working on the soils of southeastern Tanzania.

Table 12. Correlations among some chemical properties of the soils of studied fields in Biharamulo District, Tanzania.

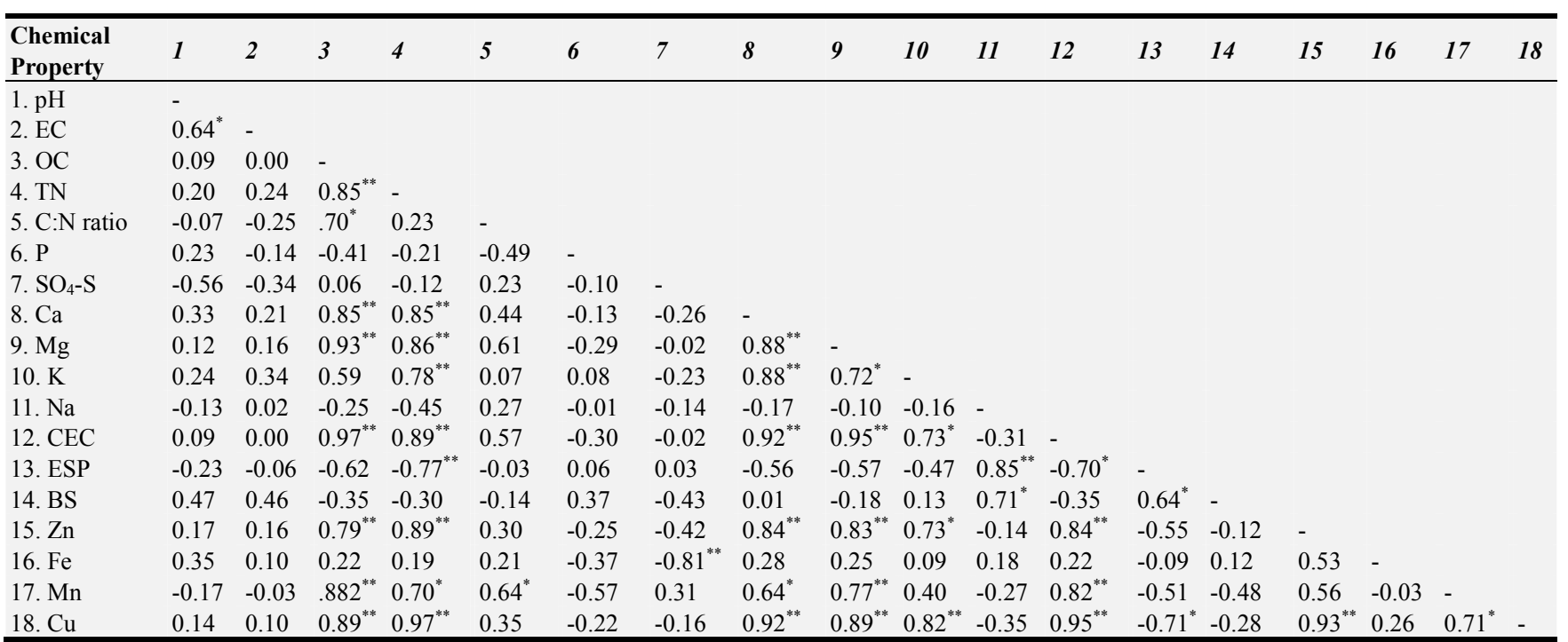

Pearson's correlation at $95 \%$ confidence level, * significant at $\mathrm{P} \leq 0.05$, ** significant at $\mathrm{P} \leq 0.01$; where $\mathrm{P}$ is the probability.

Chemical property: $\mathrm{EC}=$ electrical conductivity, $\mathrm{OC}=$ organic carbon, $\mathrm{TN}=$ total nitrogen, $\mathrm{C}: \mathrm{N}=$ carbon: nitrogen ratio, $\mathrm{P}=$ phosphorus, $\mathrm{SO} \mathrm{O}_{4} \mathrm{~S}=\mathrm{sulphate}-\mathrm{sulphur}$, $\mathrm{Ca}=$ calcium, $\mathrm{Mg}=$ magnessium, $\mathrm{K}=$ potassium, $\mathrm{Na}=$ sodium, $\mathrm{CEC}=$ cation exchange capacity, $\mathrm{ESP}=$ exchangeable sodium percent, $\mathrm{BS}=$ base saturation, $\mathrm{Zn}=\mathrm{zinc}$, $\mathrm{Fe}=$ iron, $\mathrm{Mn}=$ manganese, $\mathrm{Cu}=$ copper.

\subsubsection{Soil Fertility Status of the Studied Fields in Bukoba, Missenyi and Biharamulo Districts, Tanzania}

Based on soil fertility index, which integrate all soil parameter analyzed indexes [37-39]; the soil fertility statuses of the fields in Bukoba District ranged from poor fertility to moderate fertility. In Missenyi District, they ranged from poor to good fertility. In Biharamulo District, the soil fertility statuses of the fields ranged from poor fertility to marginal fertility (Table 13). In Bukoba District, about 55\% 27\% and $18 \%$ of the fields had poor fertility, marginal fertility and moderate fertility, respectively while in Missenyi District, about $9 \%$ and $91 \%$ the fields had poor and good fertility, respectively. In Biharamulo District, about $55 \%$ and $45 \%$ of 
the fields had poor fertility and marginal fertility, respectively (Table 14). The results summed over the total number of the studied fields revealed that about $66.7 \%$ of the studied fields had poor, marginal and moderate fertility status and $33.3 \%$ had good fertility status; hence, soil fertility management practices are desirable in those fields with poor to moderate fertility status. For example, use of inorganic fertilizers such CAN, NPK, TSP, DAP, MOP, Minjingu Mazao and/or YaraMila fertilizers (Winner, Cereal, Complex, Java) is desirable to improve $\mathrm{N}, \mathrm{P}, \mathrm{K}, \mathrm{S}$ and micronutrient contents in those fields with inadequate levels of these nutrients. The use of organic fertilizers such as farmyard manure, compost and incorporation of green manure and crop residues in the soils is desired to improve nutrient holding capacity of the soils, soil moisture conservation, soil particle aggregation, tilth, $\mathrm{C}: \mathrm{N}$ ratio and addition of nutrients in the soils [17]. Moreover, use of liming materials such $\mathrm{CaCO}_{3}, \mathrm{MgCO}_{3}, \mathrm{Ca}(\mathrm{OH})_{2}$ and $\mathrm{Mg}(\mathrm{OH})_{2}$ is desirable to increase the $\mathrm{pH}$ of the soils [3] since about $56.3 \%$ of the studied fields had strongly acid soil $\mathrm{pH}$, at the range of $5.1-5.5$ (Table 5).

Table 13. Soil fertility status of the studied fields based on soil fertility index in Bukoba, Missenyi and Biharamulo Districts, Tanzania.

\begin{tabular}{|c|c|c|c|c|}
\hline District & Village & Soil sampling site & Soil fertility index & Soil fertility status \\
\hline \multirow[t]{11}{*}{ Bukoba } & Butairuka & Rushabirwa farm & 15 & Poor fertility \\
\hline & & Mpanju farm & 15 & Poor fertility \\
\hline & & Kahigi farm & 13 & Poor fertility \\
\hline & & Bana farm & 26 & Marginal fertility \\
\hline & & Kyabitara farm & 30 & Marginal fertility \\
\hline & Kiilima & Degratias farm & 51 & Moderate fertility \\
\hline & & Ifunya farm & 14 & Poor fertility \\
\hline & & Baguma farm & 25 & Marginal fertility \\
\hline & & Respicius farm & 9 & Poor fertility \\
\hline & & Godwin farm & 64 & Moderate fertility \\
\hline & & TARI Maruku Centre & 3 & Poor fertility \\
\hline \multirow[t]{11}{*}{ Missenyi } & Igayaza & Farmers Extension Centre & 255 & Good fertility \\
\hline & & Masood farm & 253 & Good fertility \\
\hline & & Kaloli farm & 361 & Good fertility \\
\hline & & Rubega farm & 351 & Good fertility \\
\hline & & Tautus farm & 355 & Good fertility \\
\hline & Mabuye & Mhonge farm & 230 & Good fertility \\
\hline & & Maida farm & 329 & Good fertility \\
\hline & & Mabuye society & 117 & Good fertility \\
\hline & & Pascal farm & 316 & Good fertility \\
\hline & & Gervas farm & 97 & Good fertility \\
\hline & & Mabuye Primary school & 15 & Poor fertility \\
\hline \multirow[t]{11}{*}{ Biharamulo } & Rukirwengama & Edmund farm & 24 & Marginal fertility \\
\hline & & Benjamin farm & 2 & Poor fertility \\
\hline & & Chubwa farm & 4 & Poor fertility \\
\hline & & Wilson farm & 8 & Poor fertility \\
\hline & & Mtanzania farm & 4 & Poor fertility \\
\hline & Rukaragata & Yustina farm & 29 & Marginal fertility \\
\hline & & Chinga farm & 39 & Marginal fertility \\
\hline & & Mkanirwa farm & 41 & Marginal fertility \\
\hline & & Village Office & 16 & Poor fertility \\
\hline & & Mutalemwa farm & 29 & Marginal fertility \\
\hline & & Farmers Extension Centre & 7 & Poor fertility \\
\hline
\end{tabular}

Table 14. Soil fertility status of the studied fields and their percentage in Bukoba, Missenyi and Biharamulo Districts, Tanzania.

\begin{tabular}{llll}
\hline District & Number of field & Soil fertility status & Percentage (\%) \\
\hline Bukoba & 6 & Poor fertility & 55 \\
& 3 & Marginal fertility & 27 \\
& 2 & Moderate fertility & 18 \\
Missenyi & 1 & Poor fertility & 9 \\
& 10 & Good fertility & 91 \\
Biharamulo & 5 & Poor fertility & 55 \\
& 6 & Marginal fertility & 45 \\
Overall & 20 & Poor, marginal and moderate fertility & 66.7 \\
& 10 & Good fertility & 33.3 \\
\hline
\end{tabular}

However, the calculated soil fertility indices gave the general ratings of the soil fertility status of each studied field since the factor ratings are based on the ranges of rating values (Table 1). Therefore, the limiting nutrients for each studied field were identified to understand the specific nutrients that may limit crop growth and development. The identified limiting nutrients were $\mathrm{P}, \mathrm{K}, \mathrm{Mg} \mathrm{Ca}$ and $\mathrm{S}$ in Bukoba District, N, S, and Ca in Missenyi District and N, P, $\mathrm{K}, \mathrm{OC}$ and $\mathrm{S}$ in Biharamulo District (Table 15). In Bukoba District, $\mathrm{K}$ was a limiting nutrient in all 11 fields followed by 
$\mathrm{Mg}$ in seven fields, $\mathrm{P}$ in six fields, $\mathrm{Ca}$ in three fields and $\mathrm{S}$ in two fields. In Missenyi District, $\mathrm{N}$ was a limiting nutrient in all 11 fields followed by $\mathrm{S}$, in six fields and $\mathrm{Ca}$ in three fields. In Biharamulo District, $\mathrm{N}$ and $\mathrm{P}$ were the limiting nutrients in all eleven fields followed by $\mathrm{K}$ in 10 fields, $\mathrm{OC}$ in six fields and $\mathrm{S}$ in four fields. Therefore, the most limiting nutrients were $\mathrm{K}$ and $\mathrm{P}$ in Bukoba District, $\mathrm{N}$ and $\mathrm{S}$ in Missenyi District and N, P, K in Biharamulo District. However, the results of percentage limitation of each limiting nutrients across all studied fields indicated that $\mathrm{N}$ and $\mathrm{K}$ were the most limiting elements $(67 \%)$ followed by $\mathrm{P}(52 \%), \mathrm{S}(32 \%), \mathrm{Mg}$ and OC (18\%) and the least was Ca (15\%) (Table 15). Other researchers [20] working on these soils of the study area reported $\mathrm{N}, \mathrm{P}, \mathrm{K}$ and $\mathrm{OC}$ to be the limiting nutrients in those soils.

Table 15. Limiting nutrients in the studied fields in Bukoba, Missenyi and Biharamulo Districts, Tanzania.

\begin{tabular}{|c|c|c|c|}
\hline District & Village & Soil sampling site & Limiting nutrients \\
\hline \multirow[t]{10}{*}{ Bukoba } & Butairuka & Rushabirwa farm & $\mathrm{P}$ and $\mathrm{K}$ \\
\hline & & Mpanju farm & $\mathrm{K}$ \\
\hline & & Kahigi farm & $\mathrm{K}$ and $\mathrm{Mg}$ \\
\hline & & Bana farm & $\mathrm{K}$ and $\mathrm{Mg}$ \\
\hline & & Kyabitara farm & $\mathrm{P}, \mathrm{K}$ and $\mathrm{Mg}$ \\
\hline & Kiilima & Degratias farm & $\mathrm{K}, \mathrm{Mg}, \mathrm{Ca}$ and $\mathrm{S}$ \\
\hline & & Ifunya farm & $\mathrm{P}, \mathrm{K}$ and $\mathrm{Mg}$ \\
\hline & & Respicius farm & $\mathrm{P}$ and $\mathrm{K}$ \\
\hline & & Godwin farm & $\mathrm{K}$ and $\mathrm{Ca}$ \\
\hline & & TARI Maruku Centre & $\mathrm{P}, \mathrm{K}$, and $\mathrm{Mg}$ \\
\hline \multirow[t]{10}{*}{ Missenyi } & Igayaza & Farmers Extension Centre & $\mathrm{N}$ and $\mathrm{Ca}$ \\
\hline & & Masood farm & $\mathrm{N}$ \\
\hline & & Kaloli farm & $\mathrm{N}$ and $\mathrm{Ca}$ \\
\hline & & Rubega farm & $\mathrm{N}$ \\
\hline & Mabuye & Mhonge farm & $\mathrm{N}$ and $\mathrm{S}$ \\
\hline & & Maida farm & $\mathrm{N}$ and $\mathrm{S}$ \\
\hline & & Mabuye society & $\mathrm{N}$ and $\mathrm{S}$ \\
\hline & & Pascal farm & $\mathrm{N}$ and $\mathrm{S}$ \\
\hline & & Gervas farm & $\mathrm{N}$ and $\mathrm{S}$ \\
\hline & & Mabuye Primary School & $\mathrm{N}$ and $\mathrm{S}$ \\
\hline \multirow[t]{9}{*}{ Biharamulo } & Rukirwengama & Edmund farm & $\mathrm{N}, \mathrm{P}, \mathrm{K}, \mathrm{OC}$ and $\mathrm{S}$ \\
\hline & & Benjamin farm & $\mathrm{N}, \mathrm{P}, \mathrm{K}$ and $\mathrm{OC}$ \\
\hline & & Chubwa farm & $\mathrm{N}, \mathrm{P}, \mathrm{K}, \mathrm{OC}$ and $\mathrm{S}$ \\
\hline & & Wilson farm & $\mathrm{N}, \mathrm{P}, \mathrm{K}$ and $\mathrm{OC}$ \\
\hline & & Mtanzania farm & $\mathrm{N}, \mathrm{P}, \mathrm{K}$ and $\mathrm{OC}$ \\
\hline & Rukaragata & Yustina farm & $\mathrm{N}$ and $\mathrm{P}$ \\
\hline & & Chinga farm & $\mathrm{N}, \mathrm{P}$ and $\mathrm{K}$ \\
\hline & & Mkanirwa farm & $\mathrm{N}, \mathrm{P}, \mathrm{K}$ and $\mathrm{S}$ \\
\hline & & Village Office & $\mathrm{N}, \mathrm{P}, \mathrm{K}$ and $\mathrm{S}$ \\
\hline Limiting nutrient & Frequency of occurrence & Limitation percent $(\%)$ & \\
\hline Nitrogen $(\mathrm{N})$ & 22 & 67 & \\
\hline Potassium (K) & 22 & 67 & \\
\hline Phosphorus (P) & 17 & 52 & \\
\hline Sulphur (S) & 12 & 36 & \\
\hline Magnessium (Mg) & 6 & 18 & \\
\hline Organic carbon (OC) & 6 & 18 & \\
\hline Calcium & 5 & 15 & \\
\hline
\end{tabular}

Based on limiting nutrients, about 15 soil fertility groups (Table 16) identified in the study area. Group 1 comprised two nutrients ( $\mathrm{N}$ and $\mathrm{S}$ ), which both found to be the limiting nutrients in six fields. Group 2 comprised four nutrients (N, P, $\mathrm{K}$ and $\mathrm{OC}$ ), which were all found to be the limiting nutrients in four fields. Group 3 comprised three nutrients $(\mathrm{P}, \mathrm{K}$ and $\mathrm{Mg}$ ), which were all found to be the limiting nutrients in three fields. Group 4 comprised two nutrients $(\mathrm{N}$ and $\mathrm{Ca}$ ), which both found to be the limiting nutrients in three fields.
Group 5 comprised five nutrients (N, P, K, S and OC), which were all found to be the limiting nutrients in two fields. Group 6 comprised four nutrients (N, P, K and S), which were all found to be the limiting nutrients in two fields. Group 7 comprised four nutrients (N, P and K), which were all found to be the limiting nutrients in two fields. Group 8 comprised two nutrients ( $\mathrm{P}$ and $\mathrm{K}$ ), which both found to be the limiting nutrients in two fields. Group 9 comprised two nutrients $(\mathrm{K}$ and $\mathrm{Mg}$ ), which both found to be the limiting 
nutrients in two fields. Group 10 comprised one nutrient $(\mathrm{N})$, which found to be the limiting nutrient in two fields.

Other groups comprised one $(\mathrm{K})$, two $(\mathrm{N}$ and $\mathrm{P})$ and $(\mathrm{K}$ and $\mathrm{Ca}$ ), four $(\mathrm{K}, \mathrm{Mg}, \mathrm{Ca}$ and $\mathrm{S}$ ) and five $(\mathrm{P}, \mathrm{K}, \mathrm{Mg}, \mathrm{Ca}$ and $\mathrm{S})$ nutrient (s), which were all found to be the limiting nutrients in one field (Table 16). The identified groups are useful for developing specific fertilizer recommendations for deploying specific soil fertility management strategies based on the limiting nutrients. Therefore, for improving the fertility status of studied fields, farmers should be advised based on the limiting nutrients in their farms.

Table 16. Soil fertility groups and their frequencies of occurrence based on the limiting nutrients in the studied fields in Bukoba, Missenyi and Biharamulo Districts, Tanzania

\begin{tabular}{|c|c|c|}
\hline $\begin{array}{l}\text { Soil fertility } \\
\text { group }\end{array}$ & $\begin{array}{l}\text { Frequency of } \\
\text { occurrence in the fields }\end{array}$ & Limiting nutrients \\
\hline Group 1 & 6 & $\mathrm{~N}$ and $\mathrm{S}$ \\
\hline Group 2 & 4 & N, P. K and OC \\
\hline Group 3 & 3 & $\mathrm{P}, \mathrm{K}$ and $\mathrm{Mg}$ \\
\hline Group 4 & 3 & $\mathrm{~N}$ and $\mathrm{Ca}$ \\
\hline Group 5 & 2 & $\mathrm{~N}, \mathrm{P}, \mathrm{K}, \mathrm{S}$ and $\mathrm{OC}$ \\
\hline Group 6 & 2 & $\mathrm{~N}, \mathrm{P}, \mathrm{K}$ and $\mathrm{S}$ \\
\hline Group 7 & 2 & $\mathrm{~N}, \mathrm{P}$ and $\mathrm{K}$ \\
\hline Group 8 & 2 & $\mathrm{P}$ and $\mathrm{K}$ \\
\hline Group 9 & 2 & $\mathrm{~K}$ and $\mathrm{Mg}$ \\
\hline Group 10 & 2 & $\mathrm{~N}$ \\
\hline Group 11 & 1 & $\mathrm{~K}$ \\
\hline Group 12 & 1 & $\mathrm{~N}$ and $\mathrm{P}$ \\
\hline Group 13 & 1 & $\mathrm{~K}$ and $\mathrm{Ca}$ \\
\hline Group 14 & 1 & $\mathrm{~K}, \mathrm{Mg}, \mathrm{Ca}$ and $\mathrm{S}$ \\
\hline Group 15 & 1 & $\mathrm{P}, \mathrm{K}, \mathrm{Mg}, \mathrm{Ca}$ and $\mathrm{S}$ \\
\hline
\end{tabular}

\section{Conclusions and Recommendations}

\subsection{Conclusions}

The results of this study indicated that soil texture of the studied many fields are favourable for growth and development of most of the crops; except few fields in Missenyi District, which had clay and sandy soil texture. The soil $\mathrm{pH}$ of the studied fields ranged from medium to strongly acid while EC was low and favourable for crop growth and development. However, the soil $\mathrm{pH}$ levels of the studied fields in Bukoba District may lead to readily availability of $\mathrm{Fe}$, deficiency of some essential nutrients, poor microbial activities and $\mathrm{P}$ fixation, hence affect the growth and development of most of the crops.

The results indicated correlation variations among the soil chemical properties due to variations in the levels of soil chemical properties. For example, in Bukoba District, soil $\mathrm{pH}$ correlated positively and significantly with exchangeable $\mathrm{P}$, implying that exchangeable $\mathrm{P}$ may be unavailable for plant uptake in the high acid soil (low $\mathrm{pH}$ ) due to $\mathrm{P}$ fixation, and vice versa. In Missenyi District, soil $\mathrm{pH}$ correlated negatively and significantly with $\mathrm{C}: \mathrm{N}$ ratio, $\mathrm{Fe}$ and $\mathrm{Cu}$ and thus implies that $\mathrm{Cu}$ and $\mathrm{Fe}$ are readily available in soil with low $\mathrm{pH}$ (acid soil) and decreases when the soil pH increases (alkaline soil).

Based on the soil fertility index (SFI), the studied fields were rated as good fertility, moderate fertility, marginal fertility and poor fertility while based on the limiting nutrients; about 15 soil fertility groups were identified. This therefore, calls for farm/site specific fertilizer recommendations.

The results of the limiting nutrients across the studied fields indicated generally that $\mathrm{N}$ and $\mathrm{K}$ were the most limiting nutrients followed by $\mathrm{P}, \mathrm{S}, \mathrm{Mg}$ and $\mathrm{OC}$ and the least was Ca. Specifically, $\mathrm{N}$ and $\mathrm{P}$ were the most limiting nutrients in Bukoba District, $\mathrm{N}$ and $\mathrm{S}$ in Missenyi District and $\mathrm{N}, \mathrm{P}$ and $\mathrm{K}$ in Biharamulo District.

\subsection{Recommendations}

As a consequence of the results obtained in this study, the following are recommended:

1. To improve soil fertility status of those fields with poor to marginal soil fertility status based on limiting nutrients, specific soil fertility management practices are desirable in those fields. For example, use of appropriate combinations of inorganic fertilizers such as; calcium ammonium nitrate (CAN), compound NPK, triple superphosphate (TSP), di-ammoniumphosphate (DAP), muriate of potash (MOP), sulphate of potash, potassium nitrate, potassium meta-phosphate, Minjingu Mazao, Minjingu Nafaka, Yara-Mila formulations (WINNER, CEREAL, COMPLEX, UNIK 17, JAVA) or/and Yara-Vera AMIDAS at the recommended rates can alleviate the nutrient limitations. Specific use of these fertilizers will improve $\mathrm{N}, \mathrm{P}, \mathrm{K}, \mathrm{Ca}, \mathrm{Mg}$ and $\mathrm{S}$ levels in the soils of the studied fields. Fertilizers should be applied by considering the $4 \mathrm{R}$ nutrient stewardship, which focuses on applying the right fertilizer source at the right rate, at the right time and the right place [3, 75].

2. Concurrently, increased use of organic fertilizers such as farmyard manure, compost, cover crops and incorporation of green manure and crop residues in the soils is recommended to improve nutrient holding capacity of the soils, soil moisture conservation, soil particle aggregation, soil tilth, $\mathrm{C}: \mathrm{N}$ ratio and nutrient contents in the soils [17]. It is worth to note, for example, that farmyard manure is generated in the Kibanja (Bibanja in plural) areas (home gardens) in the study area.

3. Use of liming materials such $\mathrm{CaCO}_{3}, \mathrm{MgCO}_{3}, \mathrm{Ca}(\mathrm{OH})_{2}$ $\mathrm{CaO}$ and $\mathrm{M}(\mathrm{gOH})_{2}$ is recommended to increase the $\mathrm{pH}$ of the soils in those fields with strongly acid soils and reduce high levels ( $>400 \mathrm{mg} \mathrm{Fe} \mathrm{kg-1)}$ of extractable Fe

4. Moreover, we recommend management of extractable $\mathrm{Fe}$ in those fields with Fe levels of $>400 \mathrm{mg} \mathrm{kg}^{-1}$ to decrease the current $\mathrm{Fe}$ toxicity potential. This can be done through application of P-containing fertilizers such as TSP, Minjingu Nafaka/Mazao and/or DAP and K-containing fertilizers such as muriate of potash, potassium meta-phosphate and/or potassium nitrate and organic fertilizer such farmyard manure, compost and/or crop residues to reduce the high levels of $\mathrm{Fe}$ in those soils. 


\section{References}

[1] Ogunjinmi, O. F., Kolawole G. O. and Oyeyiola, Y. (2017). Soil fertility assessment and determination of potential ameliorants for an Alfisol under long-term continuous cultivation in southwestern Nigeria. Journal of Soil Science and Environmental Management, 8 (9): 155-163.

[2] Odoemena, B., Eric, E., Paul, O., Geraldine, U., Damian, I., Augustine, O. and Francis, O. (2010). Econometric analysis of the micro-level determinants of woodland conversion to arable cropping and implications to policy. African Journal of Agricultural Research, 5 (11): 1168-1178.

[3] Sanginga, N. and Woomer, P. L. (eds.) (2009). Integrated Soil Fertility Management in Africa: Principles, Practices and Development Process. Tropical Soil Biology and Fertility Institute of the International Centre for Tropical Agriculture. Nairobi, Kenya. 263 pp.

[4] Zingore, S. (2011). Maize productivity and response to fertilizer use as affected by soil fertility variability, manure application and cropping system. Better Crops, 95 (1): 4-6.

[5] Khadka, D., Lamichhane, S., Amgain, R., Joshi, S., Vista, S. P., Sah, K., and Ghimire, N. H. (2019). Soil fertility assessment and mapping spatial distribution of Agricultural Research Station, Bijayanagar, Jumla, Nepal. Eurasian Journal of Soil Science, 8 (3): 237-248.

[6] Kangalawe, R. Y. M. (2012). Land Degradation, Community Perceptions and Environmental Management Implications in the Drylands of Central Tanzania. In: Sustainable Development: authoritative and leading edge content for environmental management. Curkovic, S. (Ed). IntechOpen, London, United Kingdom (UK). pp. 539-560.

[7] Tanimu, J., Uyovbisere, E. O., Lyocks, S. W. J. and Tanimu, Y. (2013). Effects of cowdung on the growth and development of maize crop. Greener Journal of Agricultural Science, 3 (5): 371-383.

[8] Food and Agriculture Organization (FAO) (2000). Fertilizers and their use. In: International Fertilizer Industry Association. $4^{\text {th }}$ Edition. Rome, Italy. $70 \mathrm{pp}$.

[9] United Republic of Tanzania (URT) (2012). National Sample Census of Agriculture 2007/2008, Stallholder Agriculture, Volume II, Crop Sector-National Report. National Bureau of Statistic. $417 \mathrm{pp}$.

[10] Nkuba, J., Mushongi, C. C., Merumba, M. S. and Ndyetabula, I. (2011). Baseline Study in Bukoba, Missenyi, Muleba and Biharamulo Survey Report. Maruku Agricultural Research Institute, Bukoba, Tanzania. 68 pp.

[11] Kapinga, R. Mafuru, J. Simon, J. Rwiza, E. Kamala, R. Mashamba, F. and Mlingi, N. (2005). Status of Cassava in Tanzania: Implications for future research and development. Kapinga et al. (Eds). Ministry of Agriculture and Cooperative, United Republic of Tanzania. 93 pp.

[12] Peter, D. (2012). Effects of intercropping cassava with some legumes on cassava growth performance, fertility improvement and whitefly control. Thesis for award of $\mathrm{PhD}$ Degree at the Sokoine University of Agriculture, Morogoro, Tanzania. 229 pp.

[13] Baijukya, F. P. and Folmer, E. C. R. (1999). Agro-Ecological
Zonation of the Kagera region. In: Planning the Future: Past, Present and Future Perspectives of Land Use in Kagera Region. Folmer, E. C. R., Schouten, C. and Baijukya, F. P. (Eds). Bukoba, Kagera, Tanzania. pp. 28-39.

[14] Flores-Magdaleno, H., Mancilla-Villa, O. R., Mejia-Saenz, E., Olmedo-Bolantilde, M. D. C. and Bautista-Olivas, A. L. (2011). Heavy metals in agricultural soils and irrigation wastewater of Mixquiahuala, Hidalgo, Mexico. African Journal of Agricultural Research, 6 (24): 5505-5511.

[15] Rakesh, K., Rakesh, K. U. S. and Brijesh, Y. (2012). Vertical distribution of physico-chemical properties under different toposequence in soils of Jharkhand. Journal of Agricultural Physics, 12 (1): 63-69.

[16] Khadka, D., Lamichhane, S., Shrestha, S. R., and Pant, B. B. (2017). Evaluation of soil fertility status of regional agricultural Research Station, Tarahara, Sunsari, Nepal. Eurasian Journal of Soil Science, 6 (4): 295-306.

[17] Brady, N. C. and Weil, R. R. (2017). The nature and properties of soil. $15^{\text {th }}$ Edition. Pearson Education. Essex, England. 1104 pp.

[18] Havlin, H. L., Beaton, J. D., Tisdale, S. L. and Nelson, W. L. (2010). Soil Fertility and Fertilizers: An Introduction to Nutrient Management. $7^{\text {th }}$ Edition. PHI Learning Private Limited, New Delhi. India. 516 pp.

[19] United Republic of Tanzania (URT) (2019). Kagera Region Investment Guide-2019. Kagera Regional Commissioner Office, Kagera, Tanzania. 92 pp.

[20] Merumba, M. S., Msanya, B. M., Semu, E., Semoka, J. M. (2020). Pedological characterization and suitability assessment for cassava production in Bukoba, Missenyi and Diharamulo Districts, Tanzania. American Journal of Agriculture and Forestry, 8 (4): 144-166.

[21] Oosterom, A. P., Ngailo, J. A., Kileo, R. O., Mbogoni, J. D. J., Msangi, A. S., Andriesse, W. and Van Kekem, A. J. (1999). Land Resources of Biharamulo District, Kagera region, Tanzania, International Activities Report 75. Winand Staring Centre, Wageningen. The Netherlands. 160 pp.

[22] Baijukya, F. P. (2004). Adapting to change in banana-based farming systems of Northwest Tanzania: The potential role of herbaceous legume. Thesis for the ward a PhD Degree at the Wageningen University. Wageningen. The Netherland. 192 pp.

[23] Day, P. R (1965). Particle fractionation and particle size analysis. In: Methods of Soil Analysis, Part 1. Black, C. A., Evans, D. D., White, J. L., Ensminger, L. E. and Clark, F. E. (Eds), American Society of Agronomy, Madison, Wisconsin. pp. 545-566.

[24] Moberg, J. R. (2001). Soil and Plant Analysis Manual. Revised Edition. The Royal Veterinary and Agricultural University, Chemistry Department, Copenhagen, Denmark. $137 \mathrm{pp}$.

[25] Soil Survey Staff (2014). Key to Soil Taxonomy. $12^{\text {th }}$ Edition. Natural Resources Conservation Service, United States Department of Agriculture (USDA) Handbook, Washington DC. 372 pp.

[26] Okalebo, J. R., Gathua, K. W and Woomer, P. L. (2002). Laboratory methods of soil and plant analysis: A working manual. $2^{\text {nd }}$ Edition. TSBF-CIAT and SACRED Africa, Nairobi. 127 pp. 
[27] Nelson, D. W. and Sommers L. E. (1982). Total carbon, organic carbon, and organic matter. In: Methods of Soil Analysis. II. Chemical and Microbiological properties. Second Edition. Page, A. L., Miller, R. H., Keeney, D. R., Baker, D. E., Roscoe E., Ellis, J. and Rhodes, J. D. (Eds). Madison, Wisconsin, USA. pp. 539-581.

[28] Duursma, E. K. and Dawson, R. (eds) (1981). Marine organic chemistry: Evolution, composition, interactions and chemistry of organic matter in seawater. Elsevier, Amsterdam, The Netherlands. 521 pp.

[29] Bremner, J. M. and Mulvaney, C. S. (1982). Total nitrogen. In: Methods of Soil Analysis. Part 2 Black et al. (Eds) Agronomy Monograph 9, American Society of Agronomy, Madison, Wisconsin, USA. pp. 1149-1170.

[30] Bray, R. H. and Kurtz, L. T. (1945). Determination of total organic and available forms of phosphorus in soils. Soil Science, 59: 39-45.

[31] Murphy, J. and Riley, J. P. (1962). Modified single solution method for determination of phosphate in natural waters. Analytica Chimica Acta, 27: 31-36.

[32] Chapman, H. D. (1965). Cation exchange capacity. In: Methods of Soil Analysis, Part 1. Black, C. A., Evans, D. D., White, J. L., Ensminger, L. E. and Clark, F. E. (Eds), American Society of Agronomy, Madison, Wisconsin. pp. 891-901.

[33] Thomas, G. W. (1986). Exchangeable cations. In: Methods of Soil Analysis, Part 2. Chemical and Microbiological Properties. $2^{\text {nd }}$ Edition. Page, A. L., Miller, R. H., Keeney, D. R., Baker, D. E., Roscoe E., Ellis, J. and Rhodes, J. D. (Eds). Madison, Wisconsin, USA. pp. 403-430.

[34] Van Ranst, E., Nerloo, M., Demeyer, A. and Pauwels, J. M. (1999). Manual for the soil Chemistry and Fertilizer Laboratory. Analytical Methods for soils and Plants Equipment and Management of Consumable. International Training Centre for Post-Gradutes Soil Scientists and Department of Applied Analytical and Physical Chemistry. Laboratory of Analytical Chemistry and Applied Ecochemistry, University of Ghent. 243 pp.

[35] Lindsay W. L. and Norvell W. A. (1978): Development of a DTPA soil test for zinc, iron, manganese and copper. Soil Science Society of America Journal, 42: 421-428.

[36] Landon, J. R. (1991). Booker Tropical Soil Manual. A handbook for soil survey and agricultural land evaluation in the tropics and subtropics, Longman Scientific and Technical Publishers, Essex. 474 pp.

[37] Saglam, M. and Dengiz, O. (2014). Distribution and evaluation of soil fertility based on geostatistical approach in Bafra Deltaic Plain. Turkish Journal of Agricultural Research 1 (2): 186-195.

[38] Moran, E. F., Brondizion, E. S., Tucker, J. M., Da SilvaForsberg, M. C., McCracken, S. and Falesi, I. 2000. Effects of soil fertility and land use on forest succession in Amazonia. Forest Ecology and Management, 139: 93-108.

[39] Lu, D., Moran, E. and Mausel, P. 2002. Linking Amazonian secondary succession forest growth to soil properties. Land Degradation and Development 13: 331-343.

[40] Costantini, E. A., Angelone, M. and Damiani, D. (2002). Physical, geochemical and mineralogical indicators of aging in Quaternary soils of Central Italy. In: $17^{\text {th }}$ World Congress of Soil Science, Transactions. International Union of Soil Sciences, 599: 1-9.

[41] EuroConsult (1989). Agricultural Compendium for Rural Development in the Tropics and Subtropics, $3^{\text {rd }}$ Edition. Elsevier Science Publishers. Amsterdam, The Netherland. 740 pp.

[42] National Soil Service (NSS) (1990). Laboratory procedures for routine analysis, $3^{\text {rd }}$ Edition. Agricultural Research Institute, Mlingano Tanga, Tanzania. 212 pp.

[43] Baize, D. (1993). Soil Science Analyses. A Guide to Current Use. John Wiley and Sons Ltd. West Sussex. $192 \mathrm{pp}$.

[44] Msanya, B. M., Kimaro, D. N., Kimbi, G. G., Kileo, E. P. and Mbogoni, J. D. J. (2001). Land resources inventory and suitability assessment for the major land use types in Morogoro Urban District, Tanzania: Soils and Land Resources of Morogoro Rural and Urban, Volume 4. Department of Soil Science, SUA, Morogoro, Tanzania. pp. 1-66.

[45] Kebeney, S. J., Msanya, B. M., Ng'etich, W. K., Semoka, J. M. and Serrem, C. K. (2014). Pedological characterization of some typical soils of Busia County, Western Kenya: Soil morphology, physico-chemical properties, classification and fertility trends. International Journal of Plant and Soil Science, 4 (1): $29-44$.

[46] Jones Jr, J. B. (2001). Laboratory guide for conducting soil tests and plant analysis. CRC Press LCC, Boca Raton, New York, Washington, D.C. 363 pp.

[47] Horneck, D. D., Sullivan, D. M., Owen, J. S. and Hart, J. M. (2011). Soil Test Interpretation Guide. Extension services, Oregon State University. 12 pp.

[48] Ndakidemi P. A. and Semoka J. M. R. (2006). Soil Fertility Survey in Western Usambara Mountains, Northern Tanzania. Pedosphere 16 (2): 237-244.

[49] Hazelton, P. and Murphy, B. (2016). Interpreting Soil Test Research: What do all the number mean? $3^{\text {rd }}$ Edition. Commonwealth Scientific and Industrial Research Organisation (CSIRO) Publishing. Clayton South, Australia. $186 \mathrm{pp}$.

[50] Ge, S., Xu, H., Ji, M. and Jiang, Y. (2013). Characteristics of Soil Organic Carbon, Total Nitrogen, and $\mathrm{C} / \mathrm{N}$ Ratio in Chinese Apple Orchards. Open Journal of Soil Science, 3: 213-217.

[51] Touber, L. and Kanani, J. R. (1994). Landforms and soils of Bukoba District. Bukoba District Rural Development Programme. NEDWORC, Networking in Development, The Netherland. 145 pp.

[52] Tabi, F. O., Ngobesing, E. S. C., Yinda, G. S., Boukong, A., Omoko, M., Bitondo, D. and Mvondo Ze, A. D. (2013). Soil fertility capability classification (FCC) for rice production in Cameroon lowlands. African Journal of Agricultural Research, 8 (119): 1650-1665.

[53] Tenga, J. J., Semoka, J. M. and Msanya, B. M. (2018). Assessment of soil fertility status for Bambara Groundnut Production in South-eastern Tanzania. International Journal of Plant and Soil Science, 24 (3): 1-13.

[54] Barker, A. V. and Pilbeam D. J. (2007). Handbook of plant nutrition. Taylor and Francis, London, New York. 662 pp. 
[55] Mengel K (2007) Potassium. In: Handbook of plant nutrition. Barker, A. V., Pilbeam, D. J (Eds). Taylor \& Francis Group. Boca Ratan, New York, USA. pp. 91-120.

[56] Zlatev, Z., and Lidon, F. C. (2012). An overview on drought induced changes in plant growth, water relations and photosynthesis. Emirates Journal of Food and Agriculture, 24 (1): 57-72.

[57] Tripathi, D. K., Singh, V. P., Chauhan, D. K., Prasad, S. M., and Dubey, N. K. (2014). Role of macronutrients in plant growth and acclimation: recent advances and future prospective. In: Improvement of crops in the era of climatic changes. P. Ahmad et al. (Eds.). Springer, New York, USA. pp. 197-216.

[58] Wiyantoko, B., and Rahmah, N. (2017). Measurement of cation exchange capacity (CEC) on natural zeolite by percolation method. In: AIP Conference Proceedings, Vol. 1911, 020021, No. 1, AIP Publishing LLC. Doi: $10.1063 / 1.5016014$.

[59] Food Agricultural Organization (FAO) (2006). Guidelines for Soil Description. $4^{\text {th }}$ Edition. Food and Agriculture Organization of the United Nations, Rome, Italy. $66 \mathrm{pp}$.

[60] Karuma, A. N., Gachene, C. K. K., Msanya, B. M., Mtakwa, P. W., Amuri N. and Gicheru, P. T. (2015). Soil Morphology, Physico-Chemical Properties and Classification of Typical Soils of Mwala District, Kenya. International Journal of Plant and Soil Science, 4 (2): 156-170.

[61] Esu, I. E. (1991). Detailed soil survey of National Horticultural Research Institute (NIHORT) Farm at Bunkure, Kano State, Nigeria. Institute for Agricultural Research, Ahmad Bello University, Zaria, Nigeria. 72 pp.

[62] Motsara, M. R., and Roy, R. N. (2008). Guide to laboratory establishment for plant nutrient analysis, Vol. 19. Rome: Food and Agriculture Organization of the United Nations. 219 pp.

[63] Mustapha, S., Mamman, H. K. and Abdulhamid, N. A. (2010). Status and distribution of extractable micronutrients in Haplustults in Yamaltu-Deba Local Government Area, Gombe state, Nigeria. Journal of Soil Science and Environmental Management, 1 (8): 200-204.

[64] Dos-Santos, G. C. G., Valladares, G. S., Abreu, C. A., de Camargo, O. A., and Grego, C. R. (2013). Assessment of copper and zinc in soils of a vineyard region in the state of São Paulo, Brazil. In: Applied and Environmental Soil Science. Hindawi Publishing Corporation, Sao Paulo, Brazil. 10 pp.

[65] Sillanpää, M. (1982). Micronutrients and the nutrient status of soils: A global study, FAO soils bulletin no 48, FAO. Rome, Italy. pp. 17-97.
[66] Foy, C. D., Chaney, R. L., and White, M. C. (1978). The physiology of metal toxicity in plants. Annual. Review of. Plant Physiology, 29: 511-566.

[67] Deb, D. L. and Sakal, R. (2002). Micronutrients. In: Indian Society of Soil Science. Indian Research Institute, New Delhi. pp. 391-403.

[68] Edem, S. O. and Ndaeyo, N. U. (2009). Fertility status and management implications of wetland soils for sustainable crop production in Akwa Ibom State, Nigeria. Environment, Development and Sustainability, 11 (2): 393-406.

[69] Yilmaz, K., Çelik, I., Kapur, S. and Ryan, J. (2005). Clay minerals, $\mathrm{Ca} / \mathrm{Mg}$ ratio and $\mathrm{Fe}-\mathrm{Al}$-oxides in relation to structural stability, hydraulic conductivity and soil erosion in southeastern Turkey. Turkish Journal of Agriculture and Forestry, 29 (1): 29-37.

[70] Ch'ng, H. Y., Ahmed, O. H. and Majid, N. M. (2014). Improving phosphorus availability in an acid soil using organic amendments produced from agro-industrial wastes. The Scientific World Journal, 2014: 1-6.

[71] Abreu Jr., C. H., Muraoka, T. and Lavorante, A. F. (2003). Relationship between acidity and chemical properties of Brazilian soils. Scientia Agricola, 60 (2): 337-343.

[72] Azlan, A., Weng E. R., Ibrahim. C. O. and Noorhaidah, A. (2012). Correlation between soil Organic carbon, total organic matter and water content with climate and depths of soil at different land use in Kelantan, Malaysia. Journal of Applied Science in Environmental Management, 16 (4): 353-358.

[73] Cao, L., Liu, H. and Zhao, S. (2012). Relationship between carbon and nitrogen in degraded alpine meadow soil. African Journal of Agricultural Research, 7 (27): 3945-3951.

[74] Aizat, A. M., Roslan, M. K., Sulaiman, W. N. A., and Karam, D. S. (2014). The relationship between soil $\mathrm{pH}$ and selected soil properties in 48 years logged-over forest. International Journal of Environmental Sciences, 4 (6): 1129-1140.

[75] Harold, F. R. J., Patrick, H. and Tom, W. B. (2015). The 4R nutrient stewardship: A global framework for sustainable fertilizer management. In: Managing Water and Fertilizer for Sustainable Agricultural Intensification. Drechsel, P., Heffer, P., Magen, H., Mikkelsen, R. and Wichelns, D. (Eds.). $1^{\text {st }}$ Edition. International Fertilizer Industry Association (IFA), International Water Management Institute (IWMI), International Plant Nutrition Institute (IPNI), International Potash Institute (IPI). Paris, France. pp. 65-86. 